
of Engineers $s_{\circledast}$ Engineer Research and Development Center

\title{
ERDQ
}

Flood and Coastal Systems Research and Development Program

\section{Levee Setback Utility for Mission Integration in the Sangamon River Floodplain}

Illinois Waterway

Charles H. Theiling, Thomas A. Kirkeeng, Christopher P. Haring, August 2018 and Travis A. Dahl

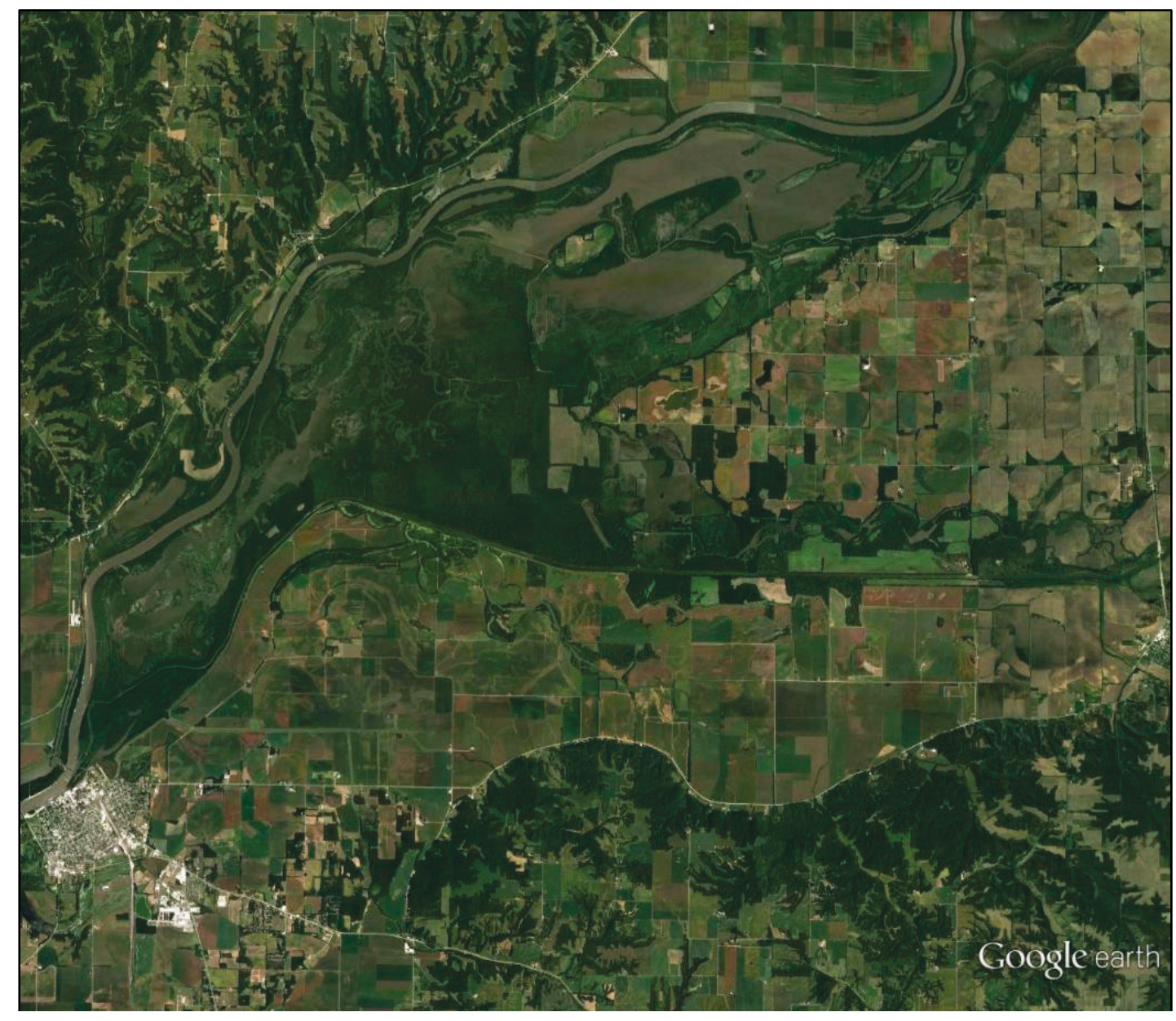


The U.S. Army Engineer Research and Development Center (ERDC) solves the nation's toughest engineering and environmental challenges. ERDC develops innovative solutions in civil and military engineering, geospatial sciences, water resources, and environmental sciences for the Army, the Department of Defense, civilian agencies, and our nation's public good. Find out more at www.erdc.usace.army.mil.

To search for other technical reports published by ERDC, visit the ERDC online library at http://acwc.sdp.sirsi.net/client/default. 


\section{Levee Setback Utility for Mission Integration in the Sangamon River Floodplain}

Illinois Waterway

Charles H. Theiling

Environmental Laboratory

U.S. Army Engineer Research and Development Center 3909 Halls Ferry Rd

Vicksburg, MS 39180-6199

Thomas A. Kirkeeng

U.S. Army Corps of Engineers, Rock Island District P.O. Box 2004, Clock Tower Bldg

Rock Island, IL 61204-2004

Christopher P. Haring and Travis A. Dahl

Coastal and Hydraulics Laboratory

U.S. Army Engineer Research and Development Center 3909 Halls Ferry Rd

Vicksburg, MS 39180-6199

Final report

Approved for public release; distribution is unlimited.

Prepared for U.S. Army Corps of Engineers

Washington, DC 20314-1000

Under Project 454633, “Evaluation of Levee Setbacks and River Restoration Projects for Flood Risk Reduction" 


\section{Abstract}

This document presents a levee setback case study on the Sangamon River near Beardstown, IL. Five potential setback scenarios were tested using a Hydrologic Engineering Center-River Analysis System (HEC-RAS) hydraulic and sediment model. HEC-RAS results demonstrated differences in flood reduction and sediment trapping opportunities among gate opening and levee-removal scenarios. Levee removal upstream of a bridge and causeway provided the greatest sediment reduction potential. Increasing flow into connected floodplain areas offered intermediate flood and sediment reduction benefits but did not improve natural resource benefits. Levee removal and land conversion provided the greatest natural resources benefit, but substantial economic loss. This study demonstrates the potential benefits of levee setbacks across the U.S. Army Corps of Engineers navigation, ecosystem restoration, and flood management mission areas.

DISCLAIMER: The contents of this report are not to be used for advertising, publication, or promotional purposes. Citation of trade names does not constitute an official endorsement or approval of the use of such commercial products. All product names and trademarks cited are the property of their respective owners. The findings of this report are not to be construed as an official Department of the Army position unless so designated by other authorized documents. 


\section{Contents}
Abstract .
ii
Figures and Tables.........................................................................................................................

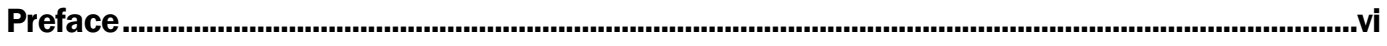
Unit Conversion Factors ...............................................................................................................vii

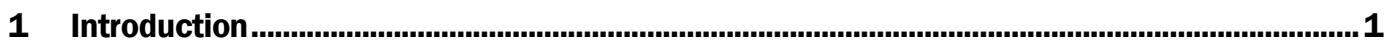

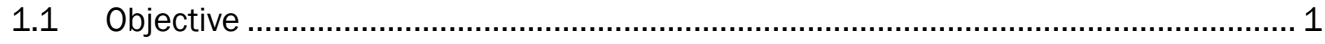

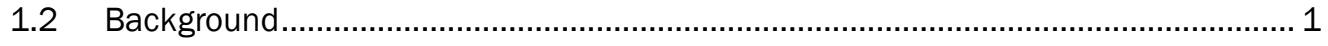

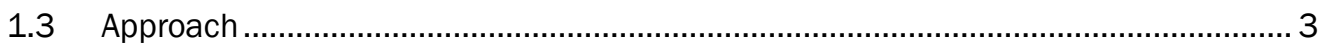

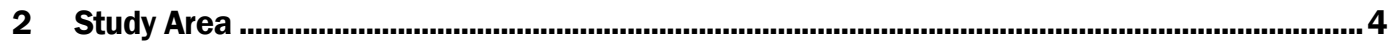

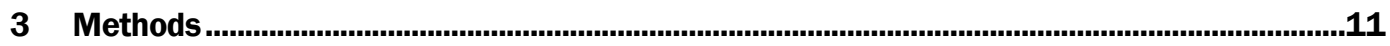

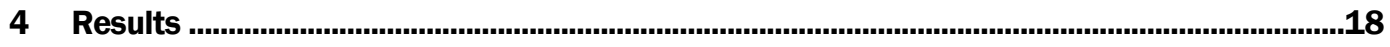

4.1 Hydrologic benefits.............................................................................................. 18

4.2 Bed-load sediment transport benefits .............................................................. 18

4.3 Overbank sediment retention benefits ............................................................. 19

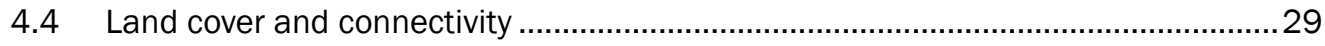

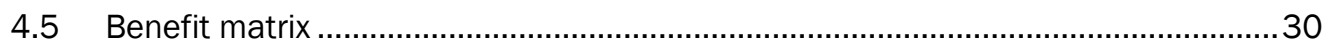

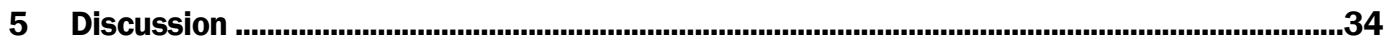

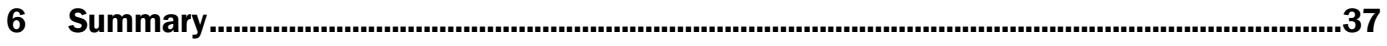

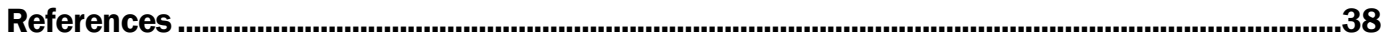

Report Documentation Page 


\section{Figures and Tables}

\section{Figures}

Figure 1. Illinois watersheds. 5

Figure 2. Sangamon River channelization ...............................................................................

Figure 3. Post channelization sedimentation in Sangamon River floodplain lakes illustrated by a 1940s photo mosaic (left) and contemporary (2013) imagery. . 7

Figure 4. Annual dredging quantities at the Sangamon River. ........................................................... 8

Figure 5. Average flow and sediment transport characteristics in the lower Sangamon

River.

Figure 6. Long-term hydrology in the lower Sangamon River.........................................................

Figure 7. Downcutting in the Sangamon River channel documented by repeated surveys between 1986 and 2009 (RM = river mile).

Figure 8. Illinois and Sangamon River HEC-RAS model boundaries and floodplain levee districts.

Figure 9. Land cover in lower Sangamon River simulated levee setback areas (L\&DD = levee and drainage district).

Figure 10. Levee setback Alternative 1A for the lower Sangamon River floodplain. Bold red lines (with arrows indicating flow directions) denote gate removal locations; purple areas represent levee protected areas; and green areas are inundated.

Figure 11. Levee setback Alternative 1B. Bold red lines indicate gate or levee removal locations; purple areas represent levee protected areas; and green areas are inundated.

Figure 12. Levee setback Alternative 2. The green line indicates the region of levee removal, and the purple areas represent levee protected areas.

Figure 13. Levee setback Alternative 3A. Bold red lines (with arrows indicating flow directions) denote gate removal locations; purple areas represent levee protected areas; and green areas are inundated..

Figure 14. Levee setback Alternative 3B. Bold red lines indicate levee removal locations; purple areas represent levee protected areas; and green areas are inundated.

Figure 15. River stage reduction (feet) levee setback Alternatives $1 \mathrm{~A}$ (dark blue dashes) and $1 \mathrm{~B}$ (light blue dashes)

Figure 16. River stage reduction (feet) for levee setback Alternative 2

Figure 17. River stage reduction (feet) for levee setback Alternatives $3 \mathrm{~A}$ (short dashes) and 3B (long dashes)

Figure 18. Longitudinal deviation of water surface elevations from baseline conditions for five lower Illinois River levee setback alternatives.

Figure 19. Modeled Lower Sangamon River bed elevation response to flooding under the base condition.

Figure 20. Lower Sangamon River bed elevation response to five levee setback alternatives, prior to flooding.

Figure 21. Lower Sangamon River bed elevation response to five levee setback alternatives immediately after flooding....

Figure 22. Lower Sangamon River bed elevation response to five levee setback alternatives, 2 months after flooding. 
Figure 23. Total sediment delivered through the lower Sangamon River (left axis, Base) and the difference attributable to five levee setback alternatives (right axis).

Figure 24. Potential land cover connected by five levee setback alternatives for the lower Sangamon River floodplain. Alternatives $1 \mathrm{~A}$ and $3 \mathrm{~A}$ use gates to support existing conditions during typical floods.

Figure 25. Levee setback benefit/harm plot of physical (stage, sediment retention), ecological (land cover), and planning considerations.

\section{Tables}

Table 1. Levee setback alternatives, names, and objectives.

Table 2. Outcomes for levee setback alternatives in the Sangamon River floodplain.

Negative retention values represent sediment storage in the lower Sangamon River ( $\mathrm{yd}^{3}=$ cubic yards) 


\section{Preface}

This study was conducted for the U.S. Army Corps of Engineers, Flood and Coastal Systems Research and Development Program, under "Evaluation of Levee Setbacks and River Restoration Projects for Flood Risk Reduction,” Project 454633. The program manager was Dr. Cary Talbot, Technical Programs Office (CEERD-HT).

The work was performed by the Ecological Resources Branch of the Ecosystem Evaluation and Engineering Division (CEERD-EE), U.S. Army Engineer Research and Development Center, Environmental Laboratory (ERDC-EL), and the River Engineering Branch (CEERD-HFR) of the Flood and Storm Protection Division (CEERD-HF), U.S. Army Engineer Research and Development Center, Coastal and Hydraulics Laboratory (ERDC-CHL).

At the time of publication of this report, Dr. Jennifer Seiter-Moser was Chief, Ecological Resources Branch (CEERD-EEE); Dr. Mark Farr was Chief, Ecosystem Evaluation and Engineering Division (CEERD-EE); the Director of ERDC-EL was Dr. Ilker Adiguzel, and the Deputy Director was Dr. Jack Davis. Mr. Keith W. Flowers was Chief, CEERD-HF-R; Dr. Cary A. Talbot was Chief, CEERD-HF; and Dr. Julie D. Rosati, CEERDHT, was the Technical Director for Flood and Coastal Storm Protection. The Acting Director of ERDC-CHL was Mr. Jeffrey R. Eckstein, and the Acting Deputy Director was Mr. John T. Tucker III.

COL Ivan P. Beckman was the Commander of ERDC, and Dr. David W. Pittman was the Director. 


\section{Unit Conversion Factors}

\begin{tabular}{|l|c|l|}
\hline Multiply & \multicolumn{1}{|l|}{ By } & To Obtain \\
\hline acres & $4,046.873$ & square meters \\
\hline cubic yards & 0.7645549 & cubic meters \\
\hline feet & 0.3048 & meters \\
\hline miles (U.S. statute) & $1,609.347$ & meters \\
\hline square miles & $2.589998 \mathrm{E}+06$ & square meters \\
\hline yards & 0.9144 & meters \\
\hline
\end{tabular}




\section{Introduction}

\subsection{Objective}

The goal of this study was to identify the potential flood risk reduction and sediment removal benefits of levee setbacks and alterations on the Sangamon River near Beardstown, IL.

\subsection{Background}

In 2006, the U.S. Army Corps of Engineers (USACE) created the Levee Safety Program with the mission to assess the integrity and viability of levees and recommend courses of action to make sure that levee systems do not present unacceptable risks to the public, property, or environment. Also in 2006, as a result of Hurricane Katrina, the National Flood Risk Management Program and the Silver Jackets programs merged to form a comprehensive approach to address local, state, and federal flood risk management issues and challenges ${ }^{1}$. Shared and residual risk are important elements of floodplain planning that are emphasized under this combined approach. Shared risk entails private, municipal, state, and federal efforts for zoning, building codes, education, planning, insurance, floodway management, and structural flood protection measures (USACE 2016b) to "buy down risk." Residual risk is "the flood risk that remains if a proposed flood damage reduction project is implemented. Residual risk includes the consequence of capacity exceedance as well" (USACE 2000). There are several factors that can change flood risk in an established project, including increased precipitation in watersheds and project areas; increased impervious surface area and runoff due to development; upstream and floodway hydrologic alterations (including increased discharge, excessive sedimentation, and floodway filling); and levee subsidence, degradation, or insufficient maintenance. The American Society of Civil Engineers (ASCE) gave U.S. levees an infrastructure condition rating of D+ (ASCE 2013).

Levee setbacks provide alternatives for floodplain managers to adapt to changing conditions (Dahl et al. 2017). The USACE can add significant experience designing flood risk management (FRM) projects with private,

\footnotetext{
${ }^{1}$ Norb Schwartz; USACE-Institute for Water Resources; personal communication; October 2014.
} 
municipal, state, and federal partners. The USACE has experience with traditional levee and floodwall design, but FRM measures are ideally part of a systemic approach to manage watersheds and significant river reaches within them. The Mississippi River and Tributaries project has 3,500 miles of levees over hundreds of river miles, but it also includes floodways that are activated to increase floodable area during extreme events (Mississippi River Commission 2007). The Yolo Bypass on the Sacramento River is another example of a high-flow FRM project. The Yolo Bypass incorporates mixed land-use (commercial agriculture and natural resources) into a system that protects the California state capitol from flooding (Sommer et al. 2001). A similar FRM bypass approach is being designed for the Red River of the North to protect Fargo, ND, for an estimated cost of $\$ 1.9$ billion (USACE 2011). The Pick-Sloan Plan on the Missouri River, conversely, used an upstream flood storage FRM model by building the largest man-made lakes in the country (Stanford University National Performance of Dams Program 2016; Wikipedia 2016) to store floods, generate electricity, irrigate crops, and support downstream navigation (USACE 2016c). Levee setbacks, designed floodways, buyouts, and other non-structural measures (USACE 2016d) are well suited for supporting system-scale FRM and need to be included as part of a suite of measures available to manage local conditions.

Recent construction projects and activities within the planning community have increased attention on levee setbacks in the USACE. Record flooding in 2011 tested several USACE FRM projects and created new opportunities for some. The Missouri River, in particular, had substantial opportunities to increase floodway capacity during flood recovery. The USACE studied several and built two levee setbacks at tight bendways in the river where levees followed sinuous banklines (Thompson et al. 2013). Smith et al. (2017) reviewed policy and conducted a review of levee setback opportunities in several parts of the country. The USACE Seattle District modeled proposed levee setback projects using a one-dimensional (1D) model and estimated significant rates of sedimentation in the setback areas. The U.S. Army Engineer Research and Development Center, Coastal and Hydraulics Laboratory (ERDC-CHL), researchers revisited this site using a two-dimensional model and predicted much lower sedimentation rates in the reconnected floodplain (Jones et al. 2018). A related research effort at ERDC-CHL established design and performance expectations for several typical levee setback designs in an effort to apply model heuristics 
to the USACE SMART ${ }^{1}$ planning process (USACE 2012) (i.e., to show expected levee setback responses for rapid alternative screening) (Echevarria-Doyle and Dahl 2018).

\subsection{Approach}

Levee setbacks on the lower Sangamon River floodplain were proposed as floodplain management alternatives to reduce flood risk and navigation channel maintenance dredging while increasing ecosystem management opportunities. Five very large floodplain management alternatives were investigated to test a suite of potential non-structural changes. The most downstream setback was conceived for river stage reduction with sediment trapping as a secondary benefit when the levee is removed. The second setback was designed to reduce river stage while increasing the potential for ecosystem benefits by increasing connectivity with a conservation area. A third setback farthest downstream was conceived as a floodplain sediment trap that would also reduce flood stages. Potential impacts and benefits to FRM, ecosystem management, and navigation channel maintenance were quantified with HEC-RAS hydraulic modeling to demonstrate mission integration co-benefits of levee setbacks. A summary matrix scoring system was developed to efficiently display the potential effects of alternative floodplain management scenarios.

The study area and methodology are detailed in Section 2 and Section 3 of this report, respectively. Section 4 details the results of the modeling effort. Section 5 discusses the findings. The conclusions are summarized in Section 6.

\footnotetext{
${ }^{1}$ Specific, Measureable, Attainable, Risk-informed, Timely
} 


\section{Study Area}

As the largest tributary to the Illinois River (Figure 1), the Sangamon River Tributary Delta functional process zone (Thorp et al. 2006) is a complex area where many ecosystem services and several USACE missions co-exist. The missions include flood control, navigation, and ecosystem restoration projects developed over 200 years of river and floodplain management. The projects have significant impacts on one another. Beardstown, IL, was established in 1826 around a ferry service at the confluence of the Illinois and Sangamon Rivers waterway corridors that connected Illinois to U.S. and world markets (Illinois State Museum 2016). The region was established as a growing port in 1834 , nicknamed "Porkopolis" for the 50,000 hogs processed annually (compared to 20,000 hogs processed daily in 2014 (Cargill 2014). Transportation projects, including navigation improvements on the river, railroads, and bridges, influenced the development of the region around Beardstown. Agriculture was the primary economic driver with 64,000 acres of levee-protected cropland in the floodplain developed since the mid-180os and prairie conversion occurring throughout the 5,419 square-mile Sangamon River watershed (Bogue 1951). Converting wet Illinois prairies was a drainage challenge accomplished with individual, commercial, and public perseverance. For example, "A ditch through the lowest part of the slough 6 to 8 feet deep, 6 feet wide at the top, soon widened to 40 , and a number of branches some 15 to 20 miles in length, built by a ditching machine run by 3 men and 12 oxen carried off the surface water into the Sangamon River" (Bogue 1951). 
Figure 1. Illinois watersheds.

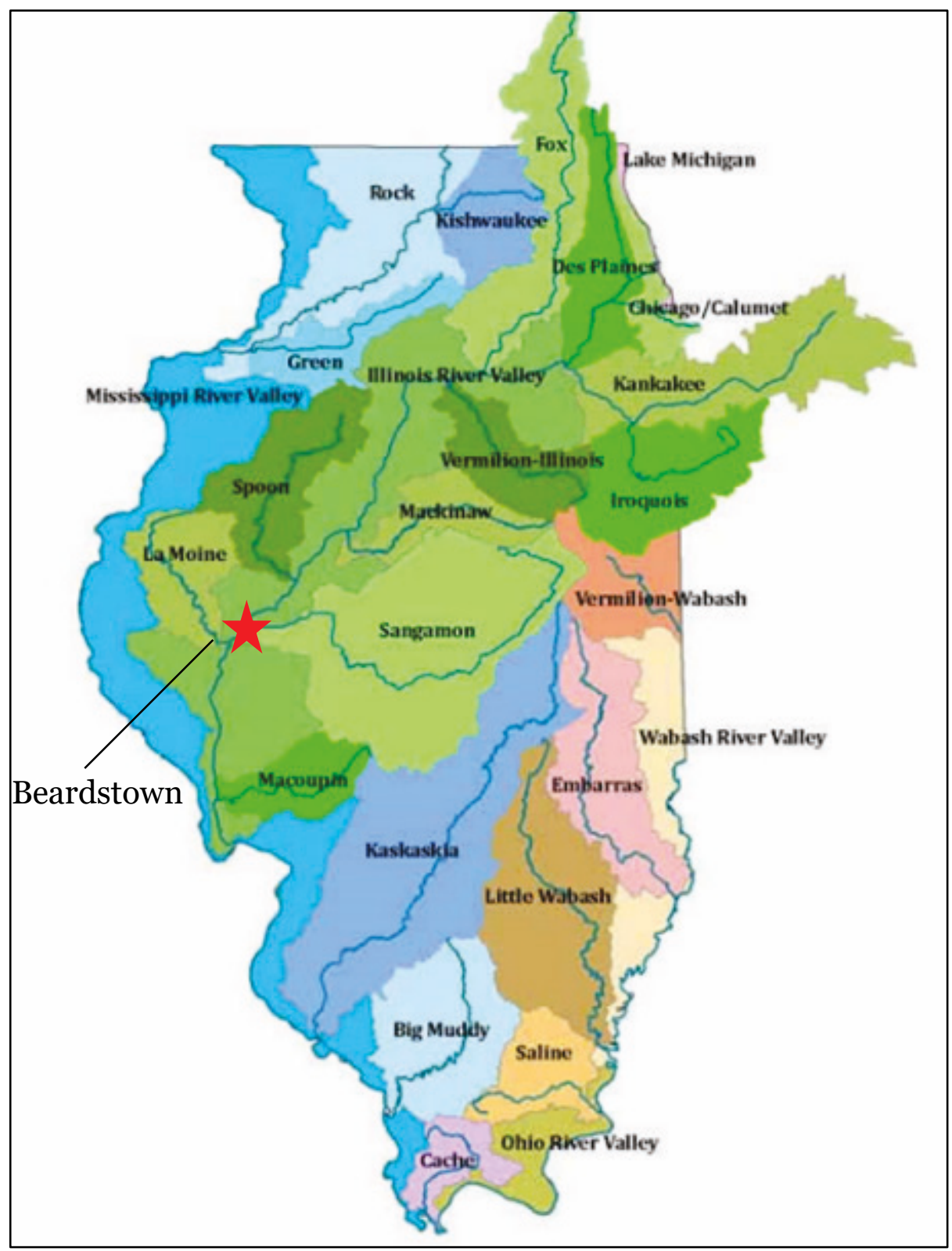

Commercial and recreational fishing and hunting have a very strong heritage in the region (Illinois State Museum 2016). The Illinois Department of Natural Resources Sanganois Conservation Area is a $>10,000-a c r e$ degraded remnant of a historically diverse and productive bottomland tributary delta ecosystem.

USACE activity in the region began with channel snagging and clearing in 1824 on the Upper Mississippi River System. Levee projects were initially built using private funding, but public funding incentives for economic development paid for improvements to them. The levees are now insured 
and regulated by public agencies and funds. Log jams were a notorious problem as Illinois hydrology was radically altered (Rhodes 2016), and numerous ineffective removal projects were attempted by private and state efforts (USACE 2004). In 1949, a congressionally authorized channelization project bypassed the log jam by straightening and shortening the Sangamon River from 63 to 36 miles between an existing conservation area and agricultural levees (Figure 2). However, that action created a sediment trap in a significant backwater lake, Muscooten Bay, which resulted in the loss of $90 \%$ of its volume and aquatic habitat value over time (Figure 3). Water depth exceeded 10 feet ( $\mathrm{ft}$ ) in some locations in 1904 whereas the entire Bay is currently less than $5 \mathrm{ft}$ deep. Maintenance dredging of the navigation channel in the Illinois Waterway (IWW) at Beardstown was an issue before the diversion, but it was essentially eliminated from 1950 to 1986 because Muscooten Bay acted as a large sediment trap (Figure 4).

Dredging the navigation channel at Beardstown is currently one of the largest IWW navigation maintenance issues, costing more than $\$ 1$ million annually to maintain. A small boat harbor authorized in 1962 has also been subject to excessive sedimentation that makes it inoperable. Recent sediment monitoring documents excessive loading of up to 20,000 tons daily during peak floods, with suspended sediment concentrations frequently exceeding 300 milligrams per liter (Figure 5$)^{1}$.

\footnotetext{
1 USACE, Rock Island District. In preparation. Report on One-Dimensional Sediment Modeling with HECRAS: Sangamon River, Illinois Regional Sediment Management. Rock Island, IL: U.S. Army Corps of Engineers, Rock Island District.
} 
Figure 2. Sangamon River channelization

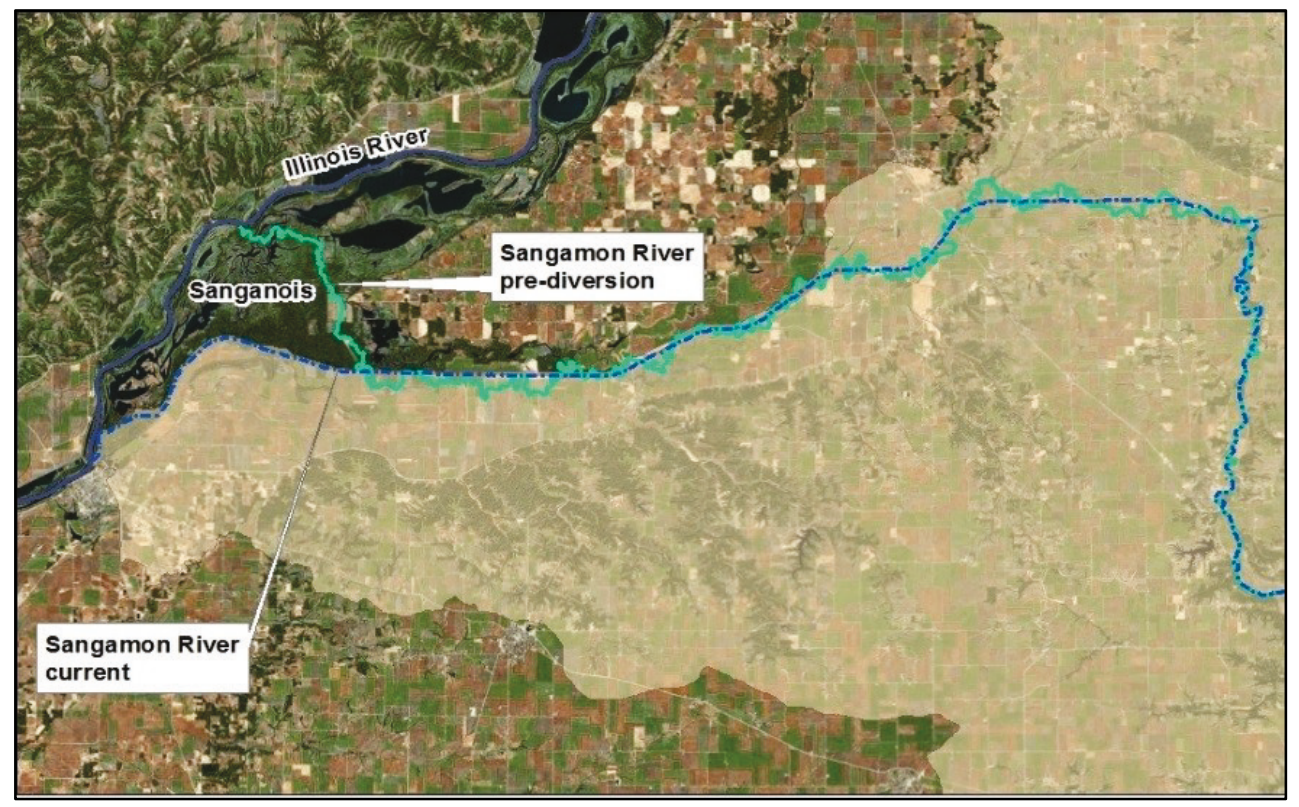

Figure 3. Post channelization sedimentation in Sangamon River floodplain lakes illustrated by a 1940s photo mosaic (left) and contemporary (2013) imagery.

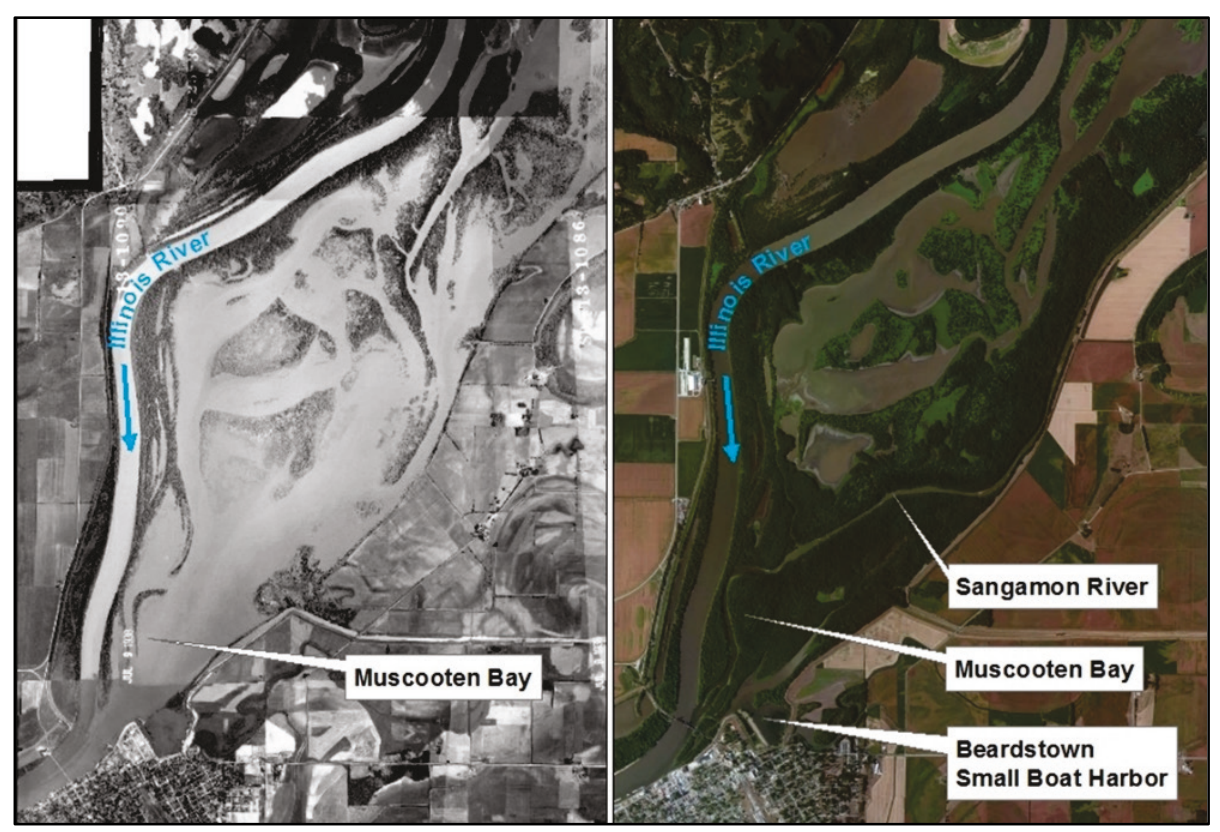


Figure 4. Annual dredging quantities at the Sangamon River.

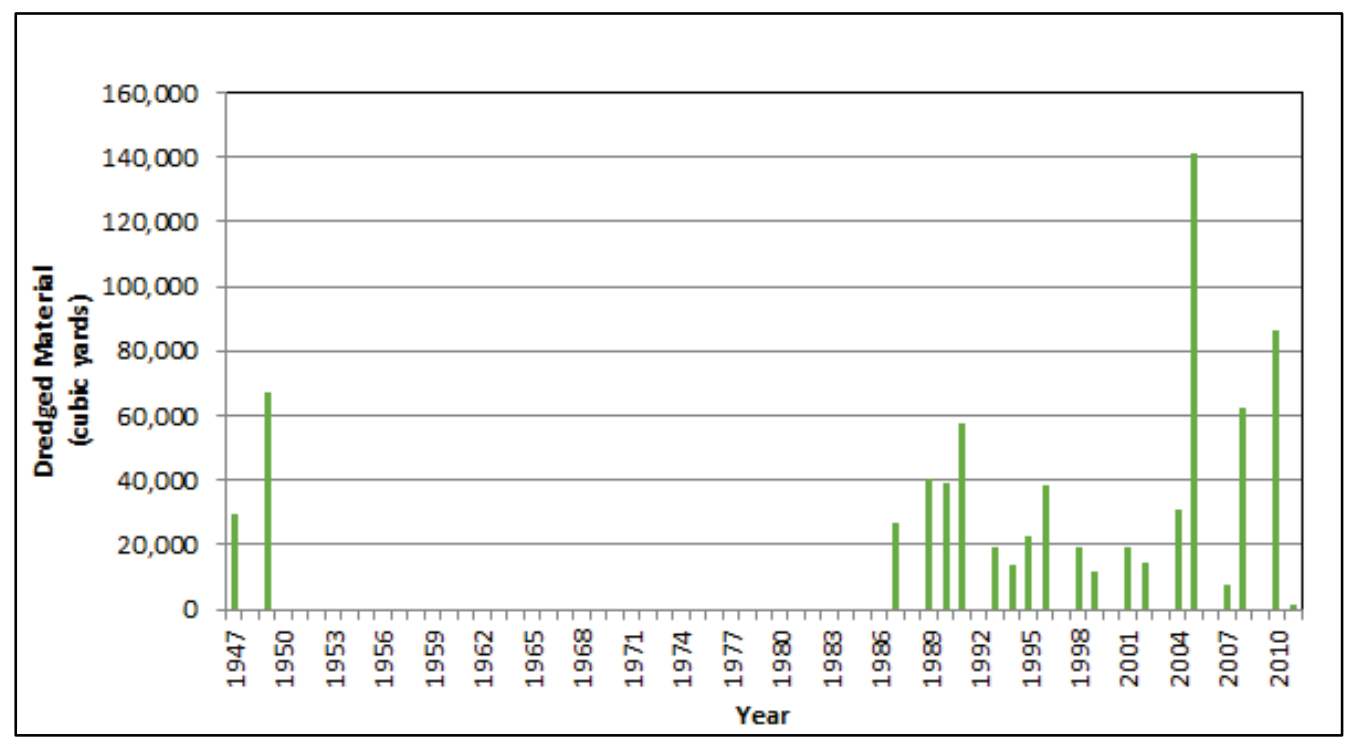

Figure 5. Average flow and sediment transport characteristics in the lower Sangamon River.

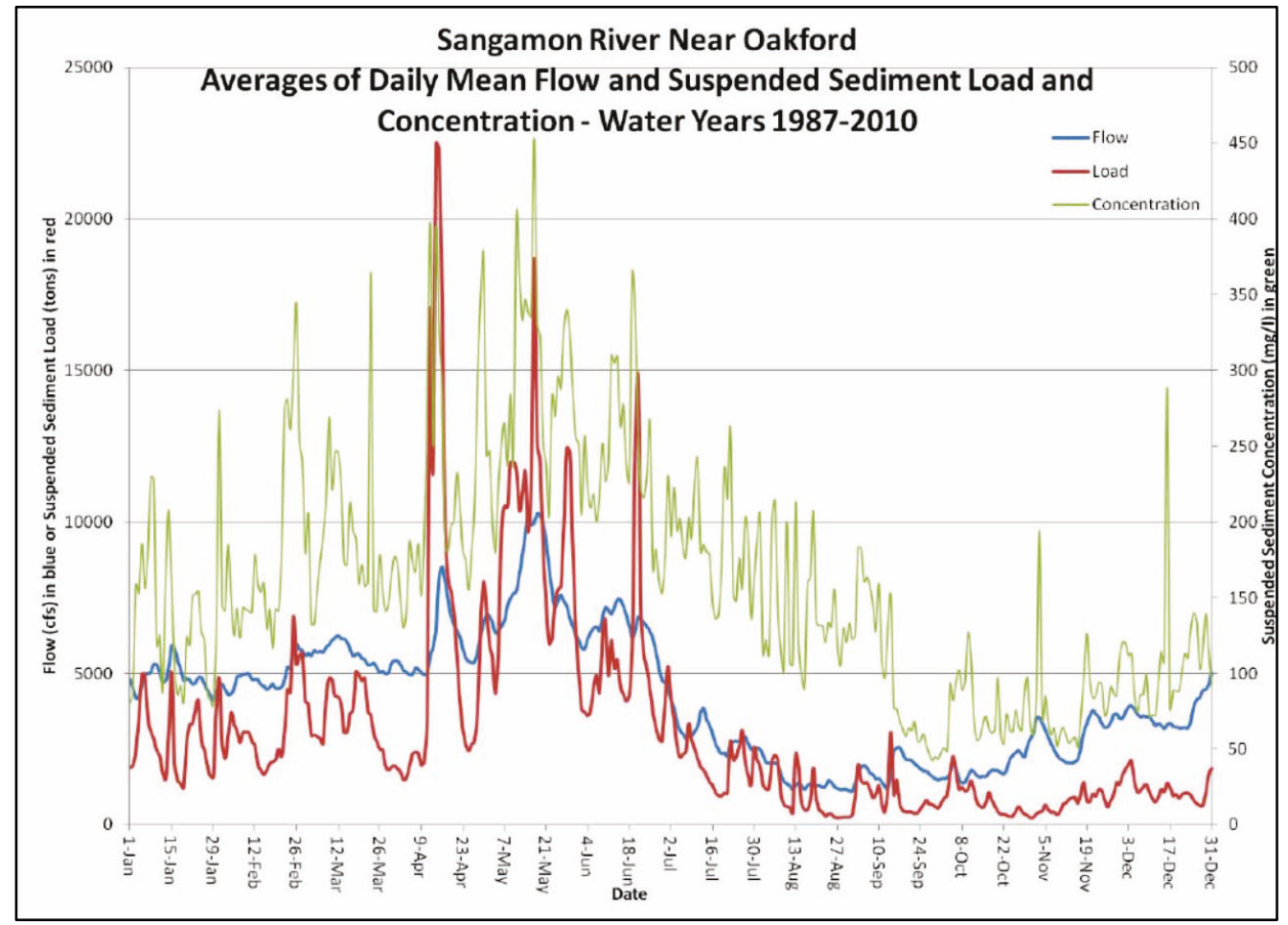

Sedimentation is a perennial problem, as is flooding (Figure 6), with record flooding most recently during 2013, summer 2015, and an unusual winter flood in December 2015 and January 2016. It is difficult to discern the exact causes of change in local flooding as precipitation, upstream hydrology, sedimentation, subsidence, and levee maintenance interact. There are indicators that link local flooding to Pacific Ocean El Nino 
events ${ }^{1}$. What is certain is that sedimentation is a continuous maintenance challenge that is driving new management alternatives. Concurrent with high overbank sedimentation rates, the main channel is downcutting, as revealed by repeated channel survey at many locations (Figure 7). Channel downcutting alters stage-discharge relationships such that less overbank flooding and aquatic habitat connectivity may occur. This downcutting is primarily redistributing sediment in the Sangamon-Illinois delta region. In the Sanganois Conservation Area, some areas have sand built up between 6 and $10 \mathrm{ft}$ above normal ground elevations.

Figure 6. Long-term hydrology in the lower Sangamon River.

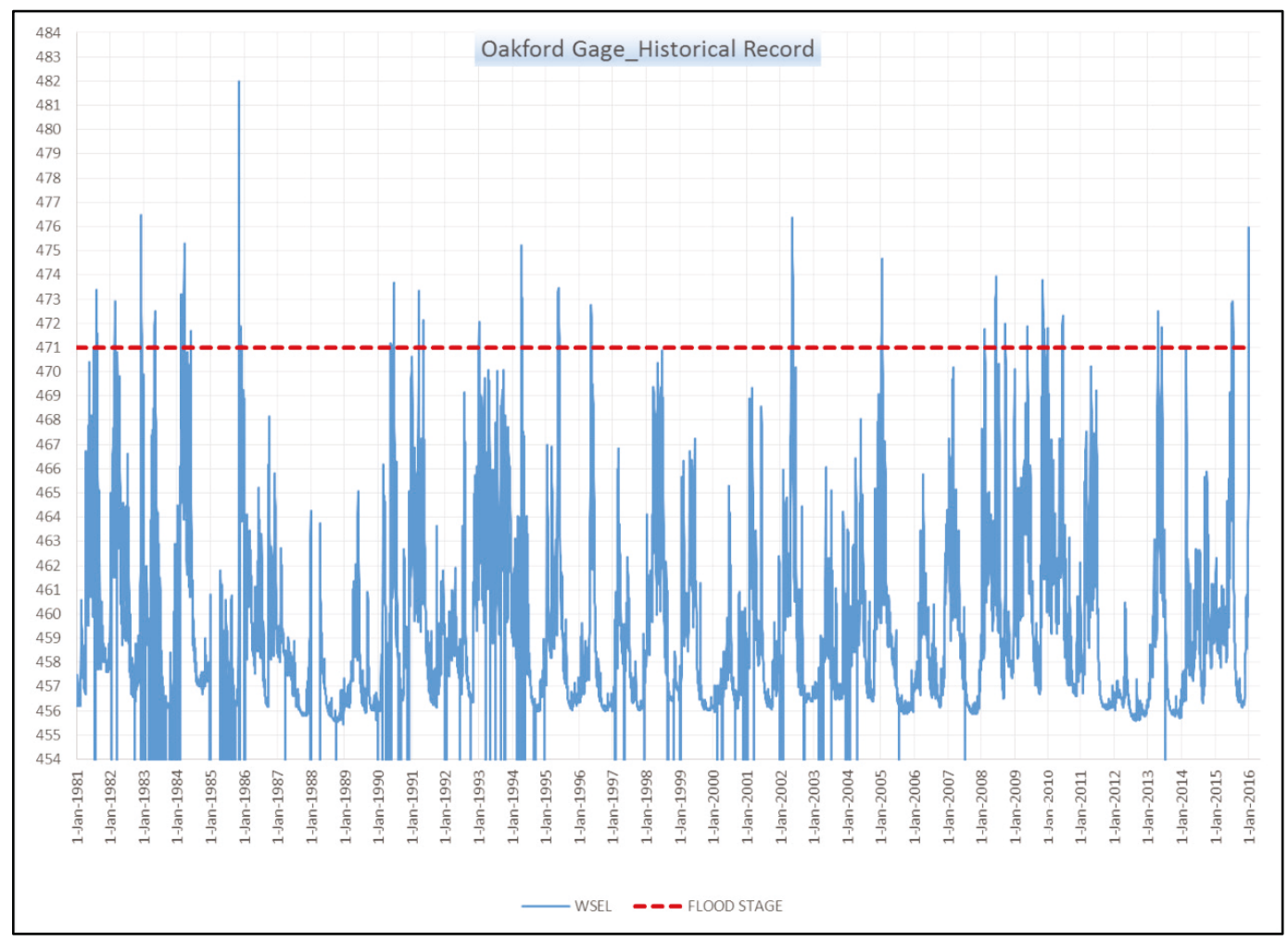

1 Anthony Heddleston; USACE; Rock Island, IL; personal communication; 30 March 2017. 
Figure 7. Downcutting in the Sangamon River channel documented by repeated surveys between 1986 and 2009 (RM = river mile).

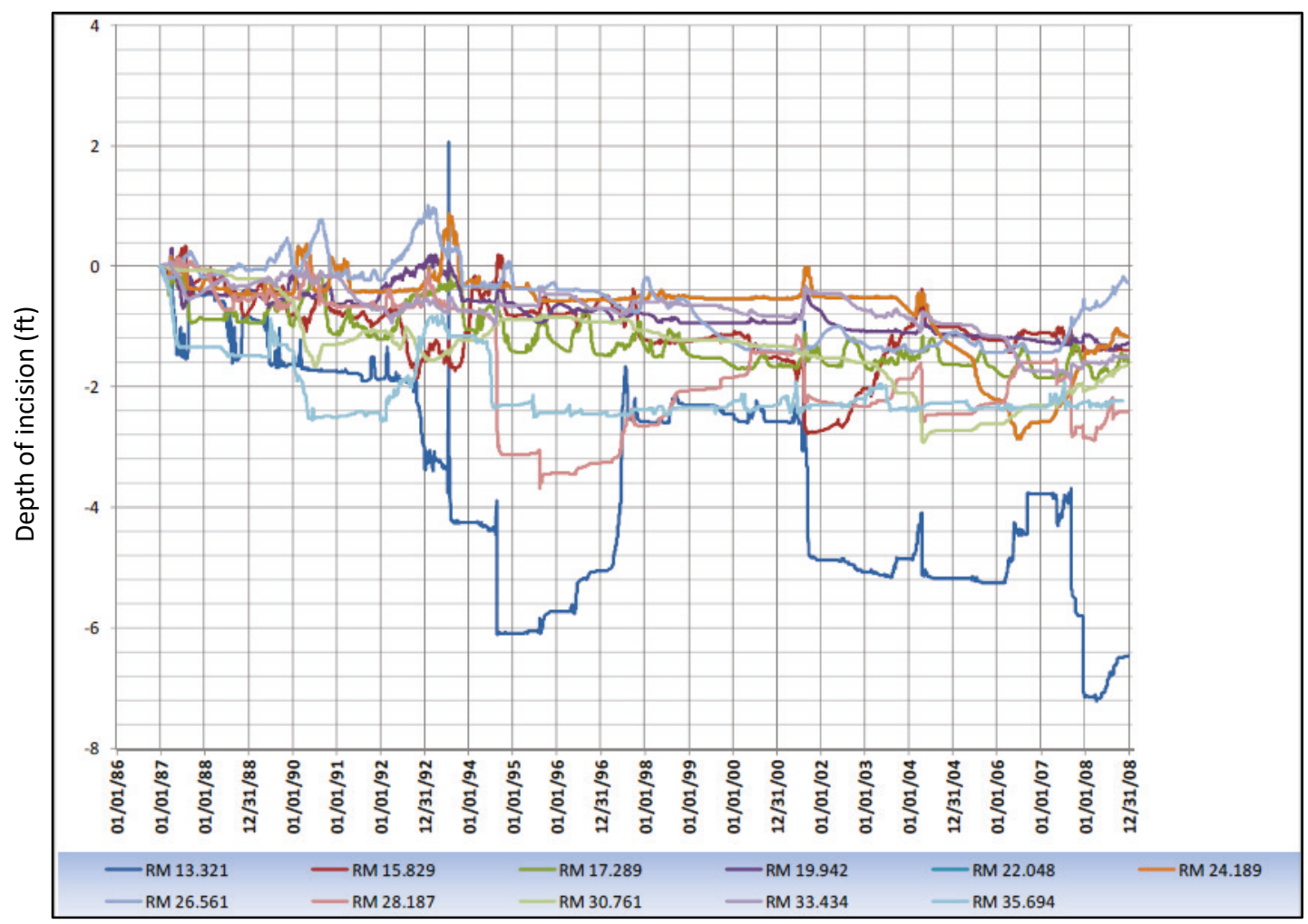

The existing condition is composed of these interacting projects and subject to changing environmental, economic, and social conditions. Costs to maintain IWW commercial navigation and levee safety are becoming untenable, as upstream sediment sources are filling channels and floodways, thus increasing navigation operations costs and also making FRM structures less effective. Levee setbacks offer a non-structural alternative for floodplain managers to consider when seeking remedial measures. Levee setbacks can achieve several mission objectives concurrently but also often require trade-offs among objectives. Levee setbacks in the Sangamon River floodplain may achieve FRM flood stage reduction and floodway protection, navigation dredging reduction, and ecosystem benefits. In this study, extreme levee setback alternatives were modeled to evaluate maximum potential response to scenarios that balance mission objectives described below (see Chapter 3 Methods). 


\section{Methods}

A HEC-RAS 1D hydraulic model with sediment transport (USACE 2016a) was constructed for the Illinois and Sangamon River confluence to understand sediment transport through the reach. ${ }^{1}$ The model spanned 42 river miles on the Illinois River and 47 miles on the Sangamon River (Figure 8). Sangamon River cross sections used in the model were surveyed by the Illinois State Water Survey in 2012. Terrestrial elevations were obtained from available lidar coverages (Illinois Geospatial Data Clearinghouse 2016).

Figure 8. Illinois and Sangamon River HEC-RAS model boundaries and floodplain levee districts.

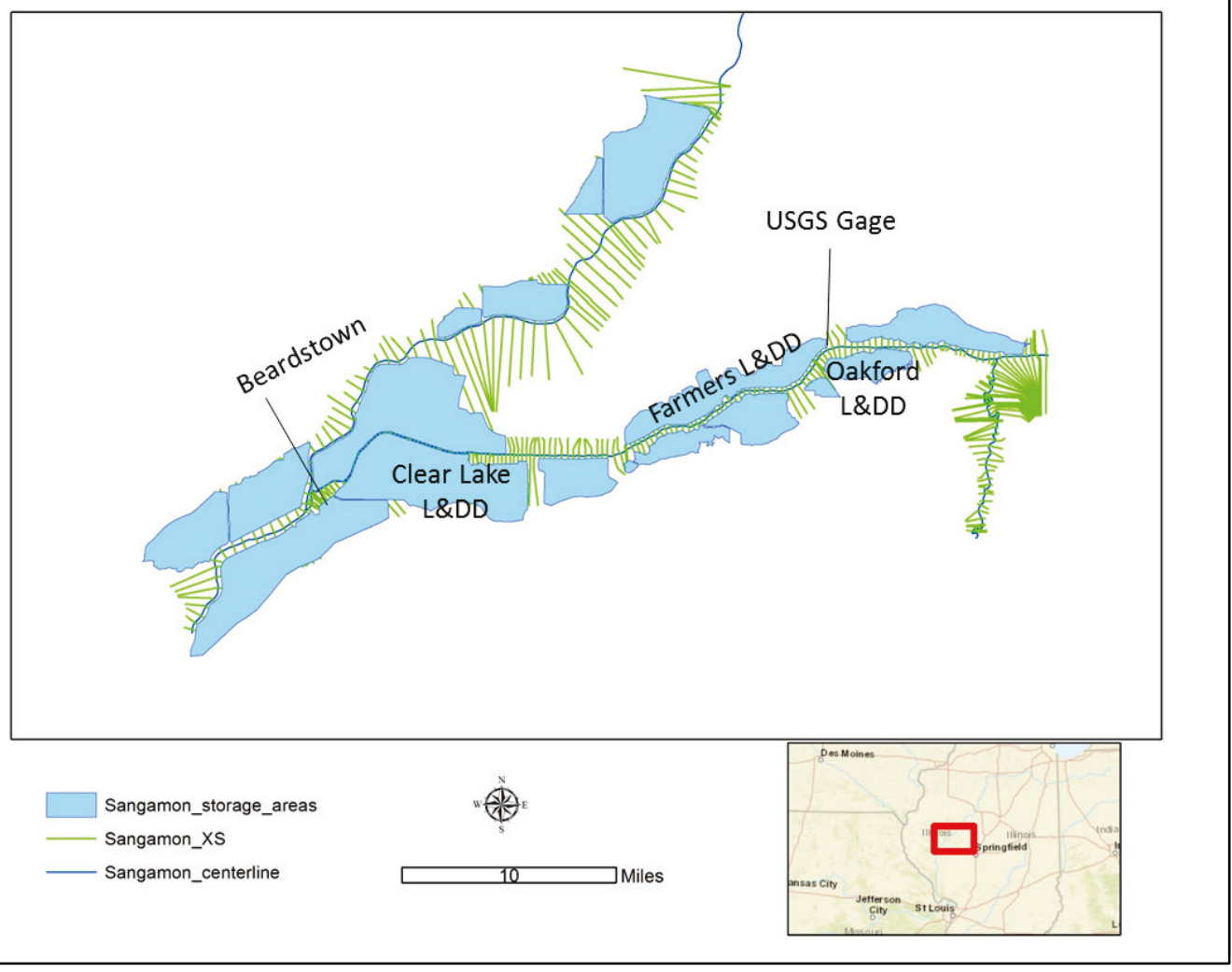

The HEC-RAS model has inflow points at the South Fork Sangamon River at Petersburg, IL; Salt Creek into the lower Sangamon at Greenview, IL; and the IWW at RM 120. There is one outflow point, on

1 USACE, Rock Island District. In preparation. Report on One-Dimensional Sediment Modeling with HECRAS: Sangamon River, Illinois Regional Sediment Management. Rock Island, IL: U.S. Army Corps of Engineers, Rock Island District. 
the IWW at La Grange Lock and Dam (RM 80). The model was calibrated hydraulically to the December 2015-January 2016 flood events, by ensuring the model produces river stages that match recorded values at gages. The sediment module was calibrated to bed trends and the suspended sediment measurements at the Oakford, IL, gage (U.S. Geological Survey 5583000).

Three floodplain locations (Figure 9) supporting five levee setback alternatives (Figure 10-Figure 14; Table 1) were tested against the base condition by running the flow and sediment modules for a record-setting flood that occurred from December 2015-January 2016. Alternatives 1A and $1 \mathrm{~B}$ were conceived as stage reduction scenarios, Alternative 2 was conceived as a conservation scenario, and Alternatives $3 \mathrm{~A}$ and $3 \mathrm{~B}$ were conceived as sediment retention actions. Alternatives $1 \mathrm{~A}$ and $1 \mathrm{~B}$ inundate much of the Clear Lake \& Hager Slough Levee \& Drainage District. Alternative $1 \mathrm{~A}$ simulates gated inlets that could be managed to prevent most flows (Figure 10) but opened as relief areas during extreme floods. Alternative $1 \mathrm{~B}$ removes the levee entirely (Figure 11), which would preclude most farming and increase connected floodplain area at all river stages. Alternative 2 simulates removing the natural levee on most of the north bank of the channelized reach and increasing flow into the Sanganois Conservation Area (Figure 12). This alternative offers opportunities to remeander some of the channelized reach with relatively little impact on agriculture compared to other alternatives. Alternatives $3 \mathrm{~A}$ and $3 \mathrm{~B}$ were conceived as sediment traps above a state highway barrier to reduce navigation dredging 25 miles downstream (Figure 13 and Figure 14). Sediment trap efficiency could be optimized for beneficial use removal as is done in the Meramec River, St. Louis, MO, for contaminant capture (Pavlowski et al. 2016).

Table 1. Levee setback alternatives, names, and objectives.

\begin{tabular}{|c|l|l|}
\hline Alternative & Name & Objective \\
\hline $1 \mathrm{~A}$ & Clear Lake gates & Stage reduction \\
\hline $1 \mathrm{~B}$ & Clear Lake removal & Stage reduction, sediment trap \\
\hline 2 & Farmers removal & $\begin{array}{l}\text { Stage reduction, sediment trap, habitat } \\
\text { connectivity }\end{array}$ \\
\hline $3 \mathrm{~A}$ & Oakford gates & Sediment trap, stage reduction \\
\hline $3 \mathrm{~B}$ & Oakford removal & Sediment trap, stage reduction \\
\hline
\end{tabular}


Figure 9. Land cover in lower Sangamon River simulated levee setback areas (L\&DD = levee and drainage district).

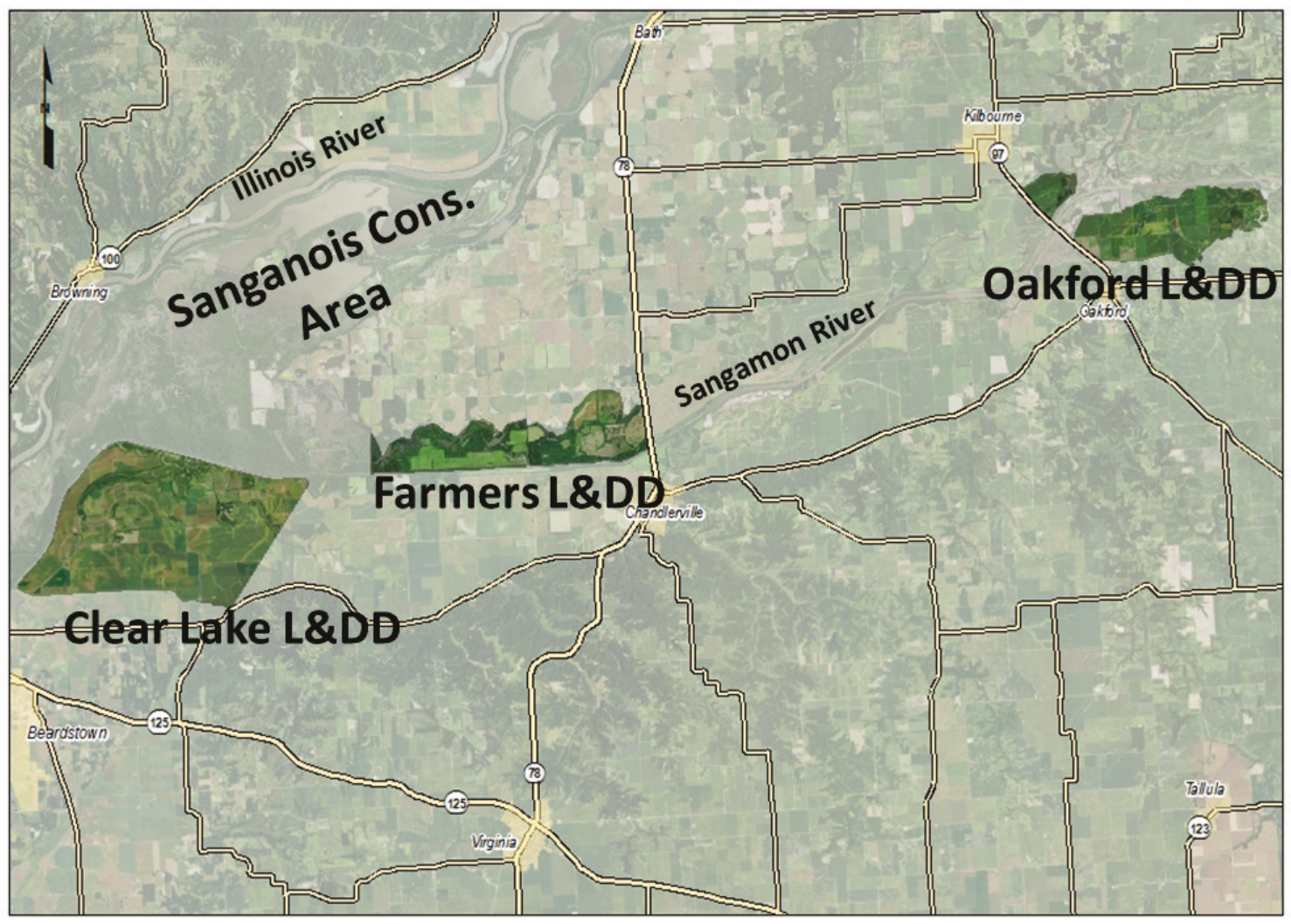

Figure 10. Levee setback Alternative 1A for the lower Sangamon River floodplain. Bold red lines (with arrows indicating flow directions) denote gate removal locations; purple areas represent levee protected areas; and green areas are inundated.

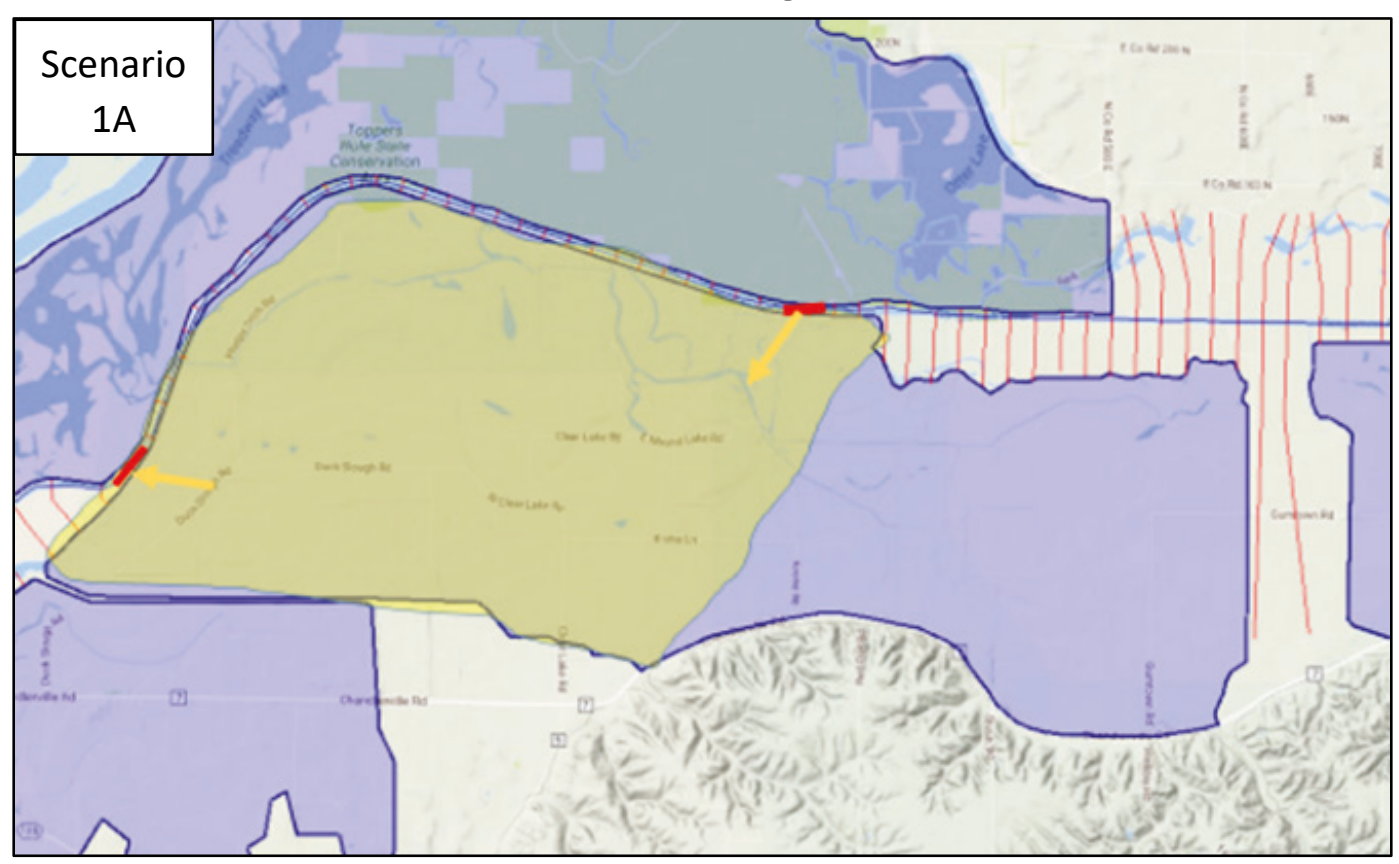


Figure 11. Levee setback Alternative 1B. Bold red lines indicate gate or levee removal locations; purple areas represent levee protected areas; and green areas are inundated.

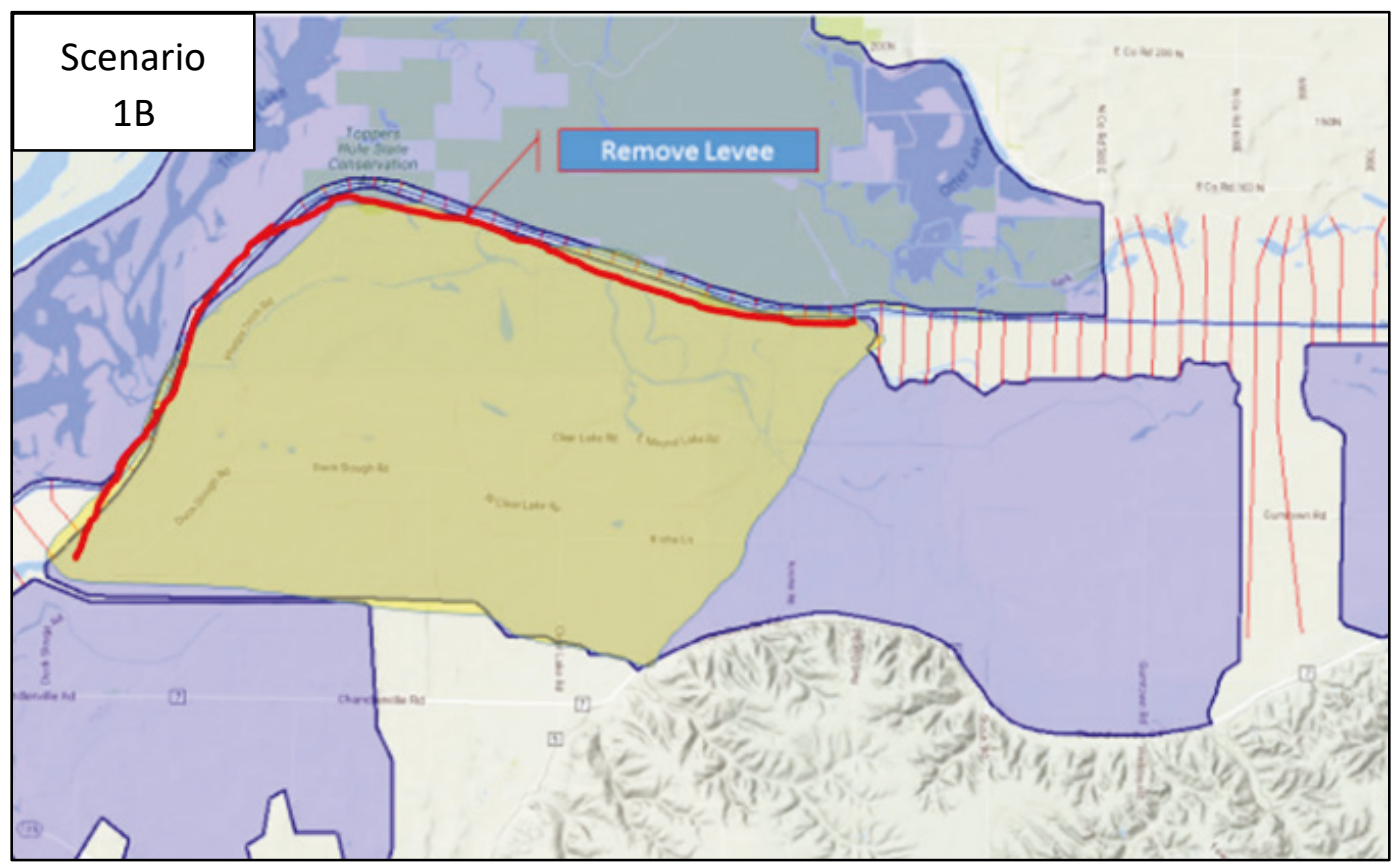

Figure 12. Levee setback Alternative 2. The green line indicates the region of levee removal, and the purple areas represent levee protected areas.

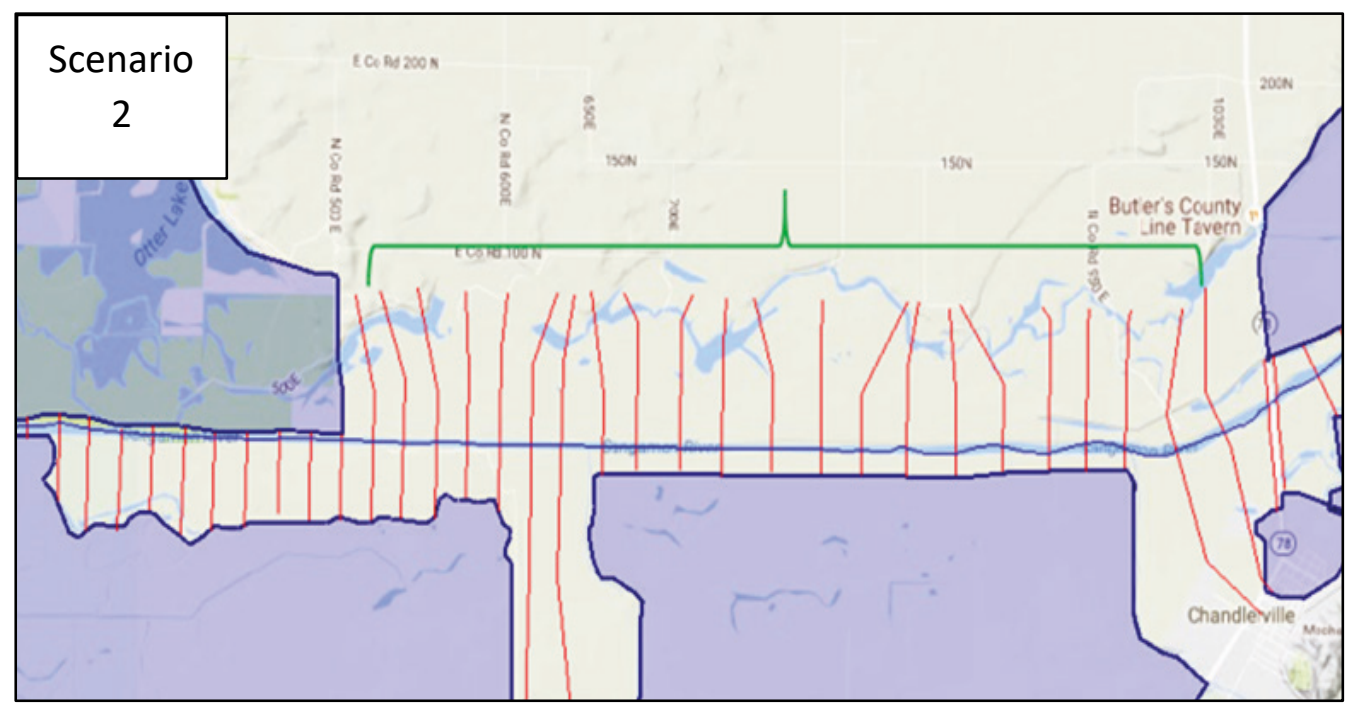


Figure 13. Levee setback Alternative 3A. Bold red lines (with arrows indicating flow directions) denote gate removal locations; purple areas represent levee protected areas; and green areas are inundated.

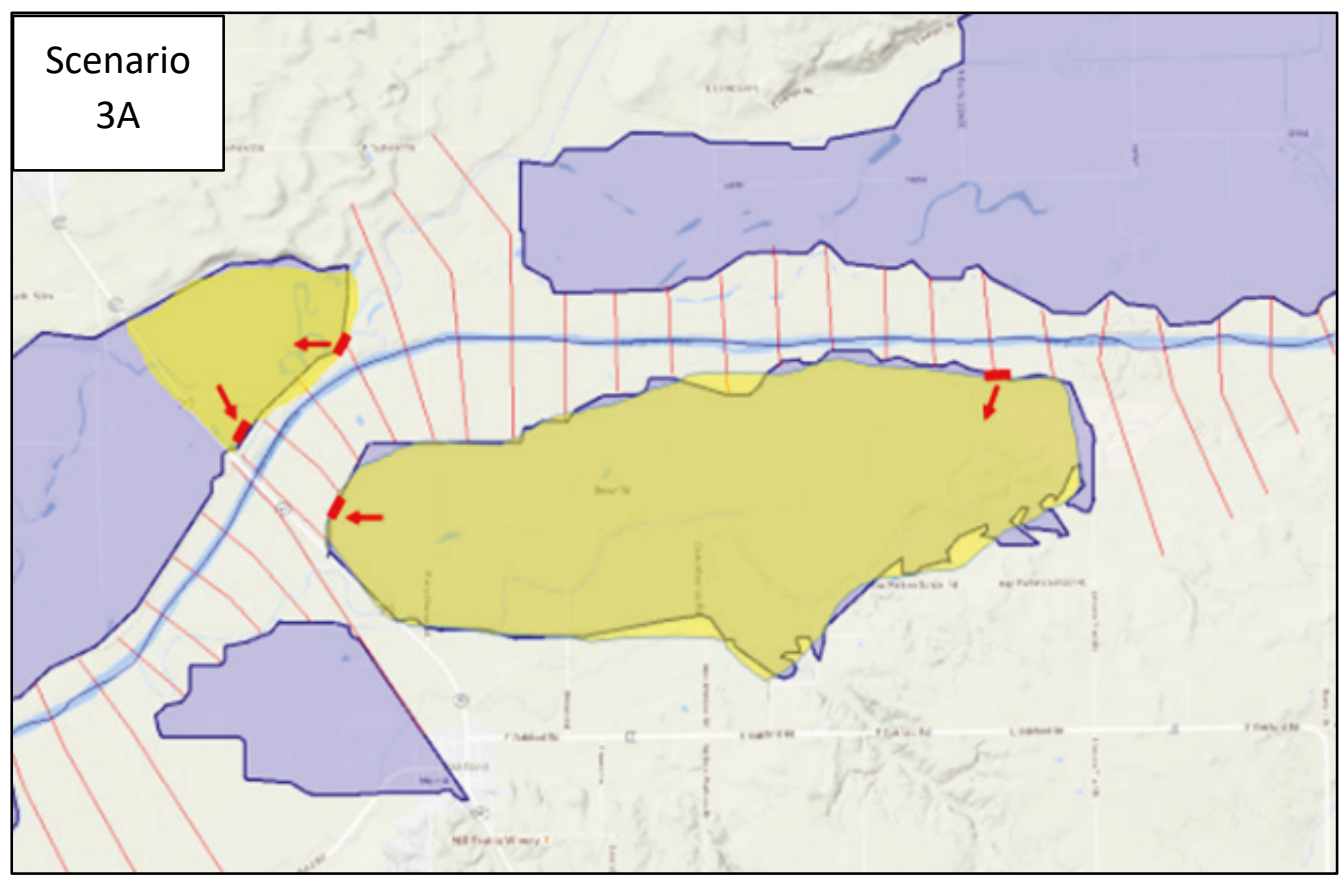

Figure 14. Levee setback Alternative 3B. Bold red lines indicate levee removal locations; purple areas represent levee protected areas; and green areas are inundated.

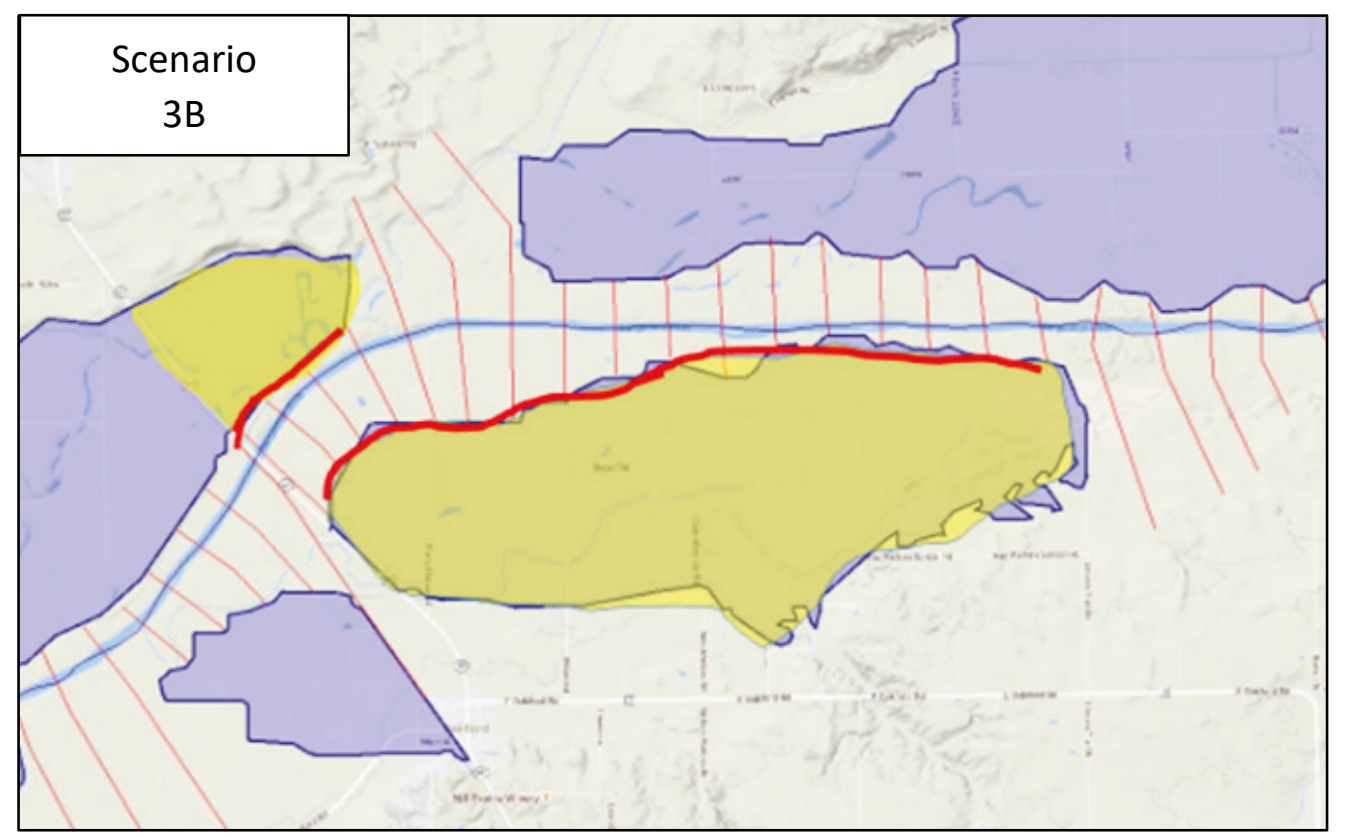

Data representing river stages, bed changes, and overbank deposition were extracted from the HEC-RAS output files. For river stages, the peak river stage that occurred during the flood event was compared for the alternatives and the base condition. For bed trends, the change in the bed 
profile that occurred during the flood event was compared against the base condition for each alternative. For overbank deposition, the volume of sediment that was diverted (as compared to the base condition) for each alternative was compared amongst all the alternatives. The amount of diverted sediment was calculated by subtracting the volume of sediment passing each cross section for a given alternative from the amount passed in the base condition model.

FRM benefits were calculated as the change in river characteristics. Bed elevation change and volume of overbank deposition at cross sections provided an estimate of sediment retention that could reduce navigation dredging. Changes were interpolated and plotted for visual inspection. Total change was calculated as the cumulative difference between the base condition and each alternative in the channel and as the total volume of sediment retained in overbank areas.

Land cover in the levee setback areas (Figure 9) was measured to compare the potential loss of agricultural land compared to gains in habitat connectivity and creation. Levee setback methods and geomorphic settings are important considerations because gated inlets or weirs act as floodways that will support agriculture in typical years and will only be used during extreme floods. Levee removal, conversely, implies a complete change of land use and restoration to conservation (i.e., habitat) objectives. Alternative 2, in this case, removes an unimproved levee on the north bank of the channelized Sangamon River. The levee is approximately $6 \mathrm{ft}$ high and only half as high as the agricultural levees on the opposite bank. The frequency of flooding in gated alternatives was not estimated, so agriculture remained as the existing condition in those scenarios, but crop acres were lost in other scenarios. Environmental benefits were characterized as wetland, forest, and aquatic acres connected to the river to compare habitat diversity and potential for different ecological communities. There was no estimate of potential land cover change on cropland; instead the setback benefit was expressed as agriculture conversion to diverse native cover and conservation objectives.

Levee setback benefits support several USACE mission areas that can be summarized succinctly for efficient planning. Each modeled or measured result was converted to a single unit, or index, of benefit/harm. Positive values of the index indicate net benefits, with larger values indicating greater benefits. Negative values are considered losses, for that category. 
Agricultural land conversion to land cover was awarded negative values on the Agriculture Index due to economic losses but was awarded positive values on the habitat and ecosystem services indices. Ecosystem services in this case were generalized in the example to include benefits of reduced flood risk, increased habitat potential, and potential sediment and nutrient reduction in overbank areas subject to flooding. 


\section{Results}

\subsection{Hydrologic benefits}

Changes for individual scenario analyses demonstrate the hydrologic response upstream from each modeled alternative (Figure 15-Figure 17). Each subplot spans the reach influenced by the modeled alternatives. The maximum water surface difference plot (Figure 18) compares the hydraulic responses of all the alternatives. Alternatives 2 and $3 \mathrm{~B}$ have maximum river stage reduction responses of greater than $3 \mathrm{ft}$ in a single location and greater than $1 \mathrm{ft}$ over a 6 -mile reach (Figure 18). Alternatives $1 \mathrm{~A}$ and $1 \mathrm{~B}$ have responses that are similar to each other, with nearly $1 \mathrm{ft}$ of stage reduction over 12 river miles. Alternative $3 \mathrm{~A}$, which uses gated inlets, shows little hydraulic response.

\subsection{Bed-load sediment transport benefits}

Changes in bed elevation in response to recent record floods demonstrate the calibration data for comparative purposes (Figure 19) and modeled output for pre-, post-, and 2-month post-flood simulations (Figure 20, Figure 21, and Figure 22, respectively). Modeled simulations mostly track with measured bed response, except for Alternative 2. RM 8-18 show the greatest change in all the plots. The magnitude of change (Table 2) is insignificant in terms of the total bed-load transport, dredging volumes, and in comparison to overbank sediment retention.

Table 2. Outcomes for levee setback alternatives in the Sangamon River floodplain. Negative retention values represent sediment storage in the lower Sangamon River ( $\mathrm{yd}^{3}=$ cubic yards).

\begin{tabular}{|l|c|c|c|c|c|}
\hline Benefit/Harm & Alt. 1A & Alt. 1B & Alt. 2 & Alt. 3A & Alt 3B \\
\hline Maximum stage reduction (ft) & 0.8 & 2.0 & 3.2 & 0.2 & 3.2 \\
\hline Bed-load retention $\left(\mathrm{yd}^{3}\right)$ & $-2,278$ & $-2,179$ & $-2,287$ & $-2,157$ & $-2,140$ \\
\hline Overbank retention $\left.(\mathrm{yd})^{3}\right)$ & $51,836,753$ & $54,318,062$ & $-1,390,838$ & $68,297,519$ & $-184,449,983$ \\
\hline Agriculture conversion (acre) & 0 & 6,939 & 1,333 & 0 & 2,849 \\
\hline Wetland connected (acre) & 0 & 39 & 110 & 0 & 2 \\
\hline Forest connected (acre) & 0 & 1,153 & 1,733 & 0 & 140 \\
\hline Aquatic connected (acre) & 0 & 54 & 175 & 0 & 0 \\
\hline Agriculture Index & -2 & -3 & -1 & -2 & -3 \\
\hline Habitat Index & 1 & 3 & 3 & 1 & 3 \\
\hline Ecosystem services Index & 2 & 3 & 1 & 2 & 3 \\
\hline Total acres in setback area & 8,555 & 8,555 & 3,468 & 3,149 & 3,149 \\
\hline
\end{tabular}




\subsection{Overbank sediment retention benefits}

Cumulative bedload going downstream during 2015-2016 floods were used to calibrate and compare overbank sediment retention simulations. Decreases in sediment transport may result in less navigation dredging or less sediment delivered to the Sanganois Conservation Area. The base condition transports sediment through levee constrained channels to RM 20 where levees are set back slightly from the channel and at tributaries (Figure 23). More sediment is retained beginning at RM 17, where the natural levee on the right descending bank constrains sediment in the channel. This continues to RM 12, where the right bank opens to the Sanganois Conservation Area. Sediment drops out dramatically through the Sanganois reach, decreasing from 3 million $\mathrm{yd}^{3}$ delivered at RM 12 to less than 250,000 yd ${ }^{3}$ delivered to the Illinois River. 
Figure 15. River stage reduction (feet) levee setback Alternatives $1 \mathrm{~A}$ (dark blue dashes) and 1B (light blue dashes).

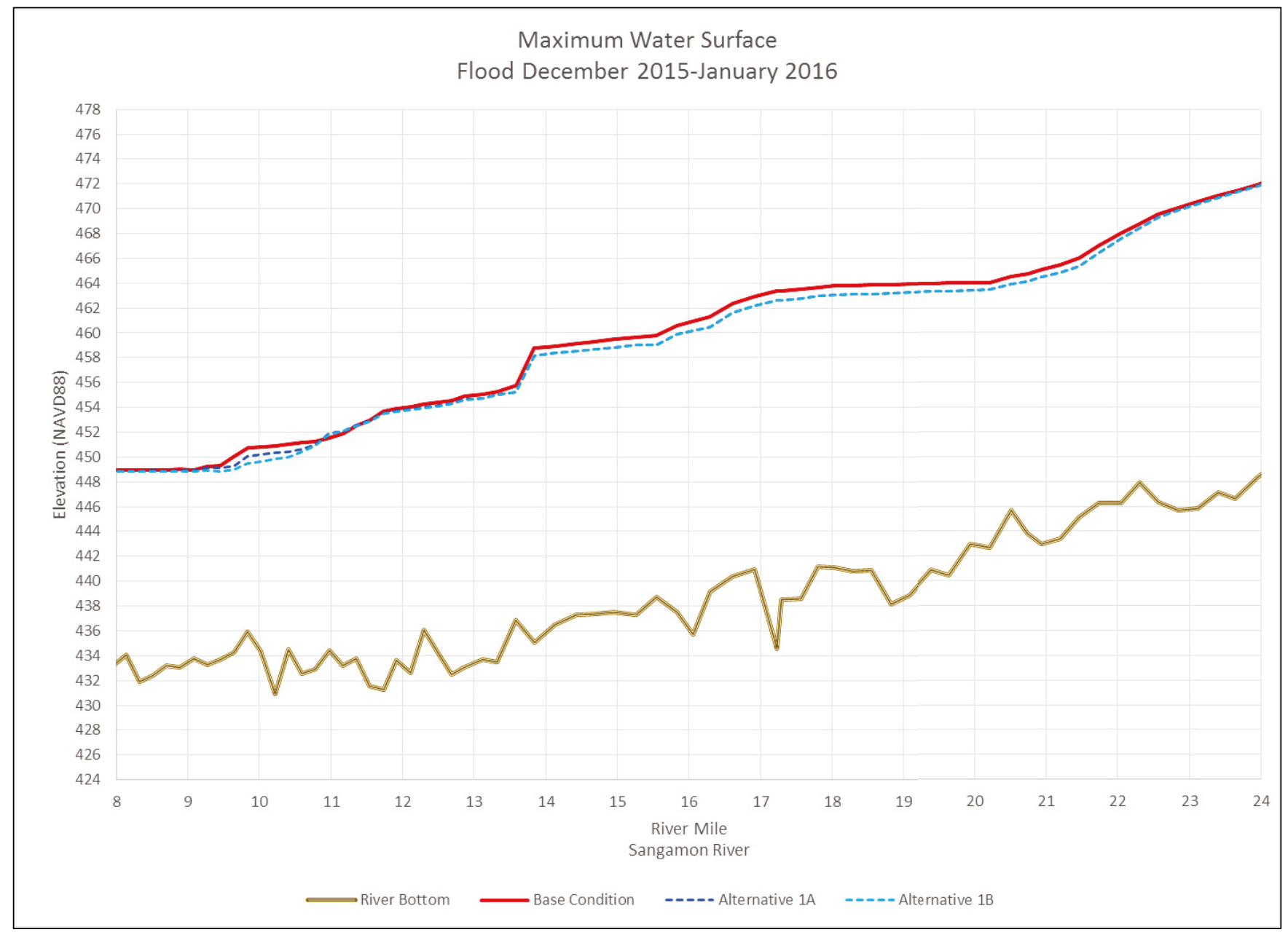


Figure 16. River stage reduction (feet) for levee setback Alternative 2.

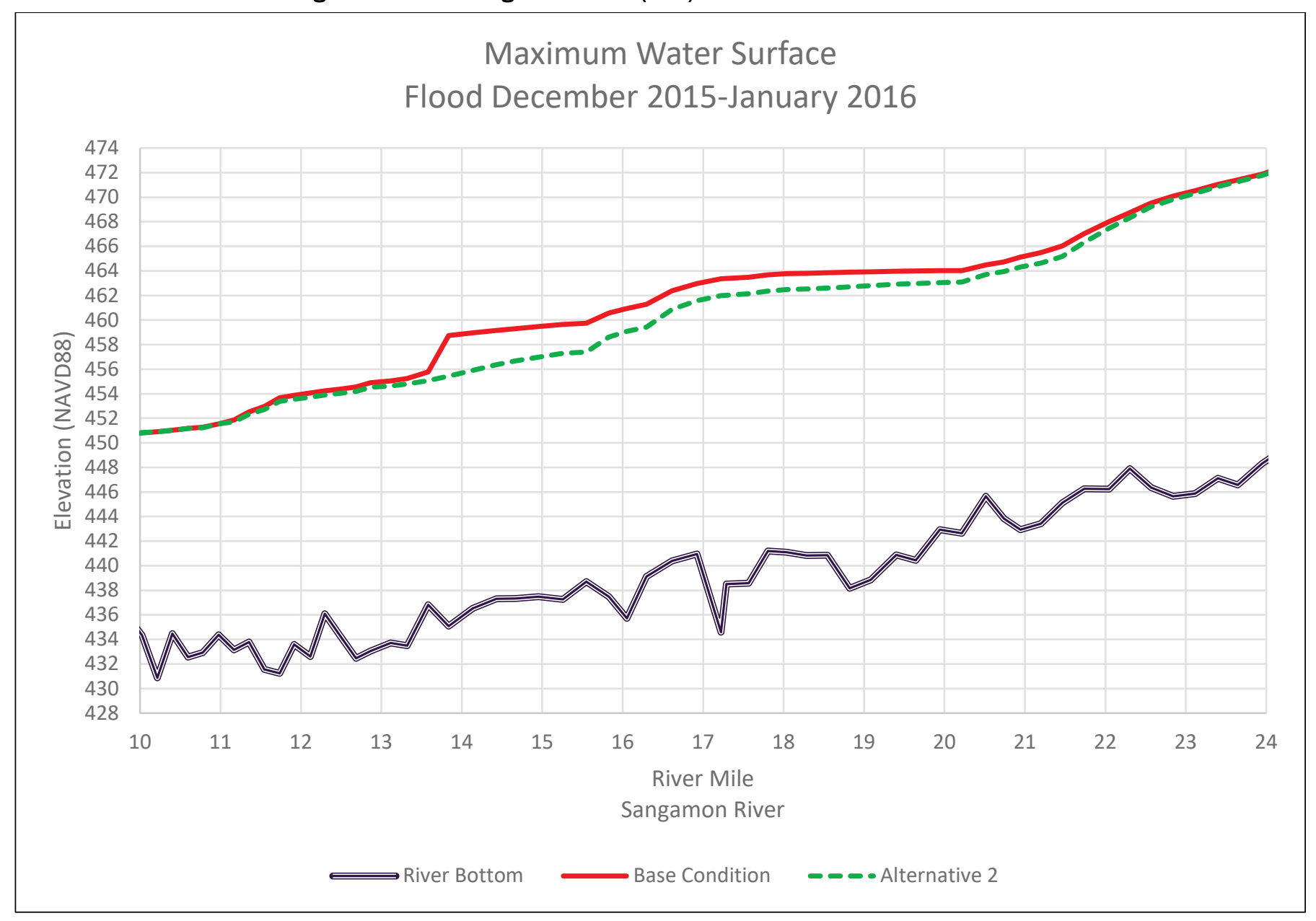




\section{Figure 17. River stage reduction (feet) for levee setback Alternatives 3A (short dashes) and 3B (long dashes).}

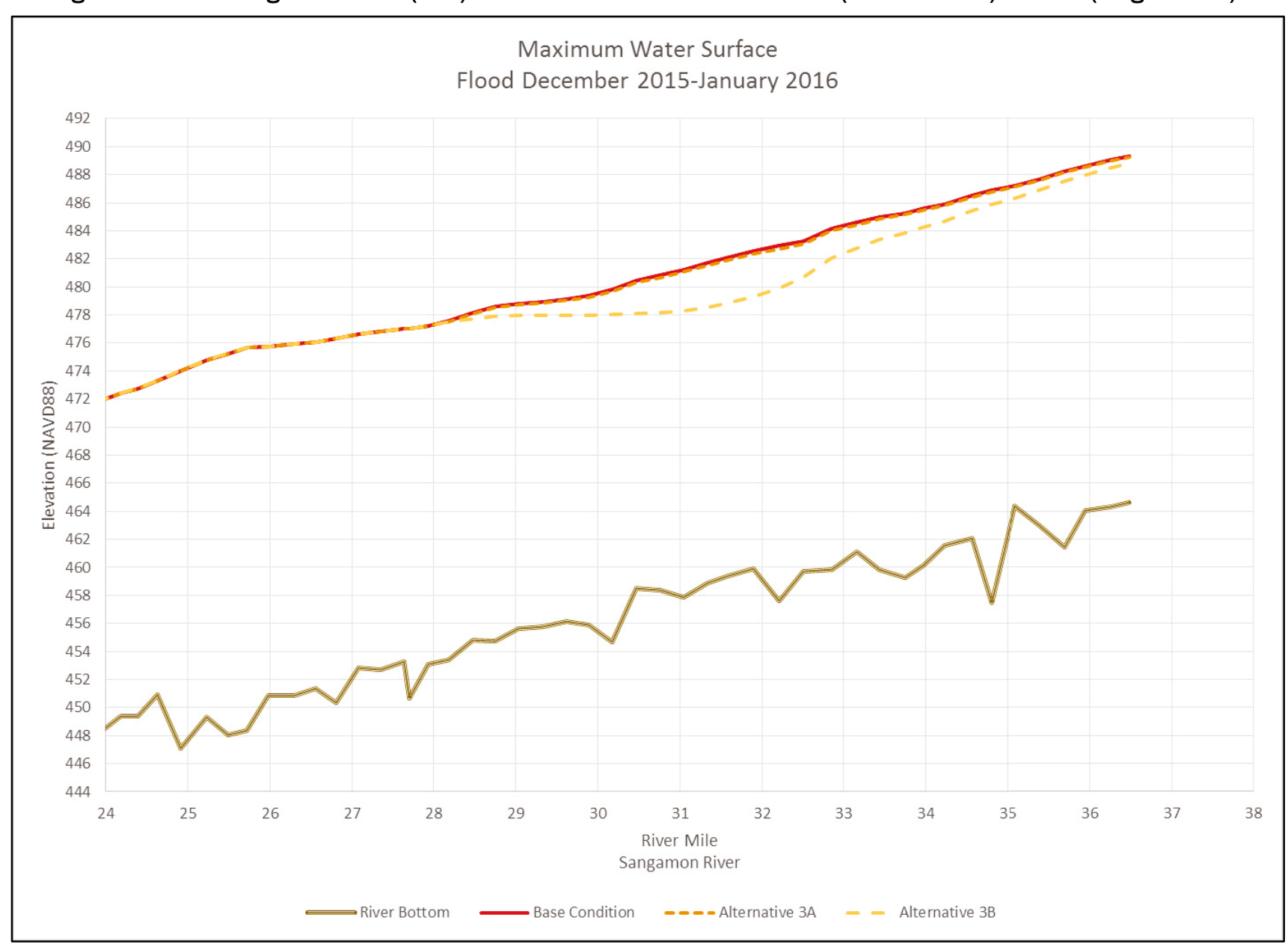


Figure 18. Longitudinal deviation of water surface elevations from baseline conditions for five lower Illinois River levee setback alternatives.

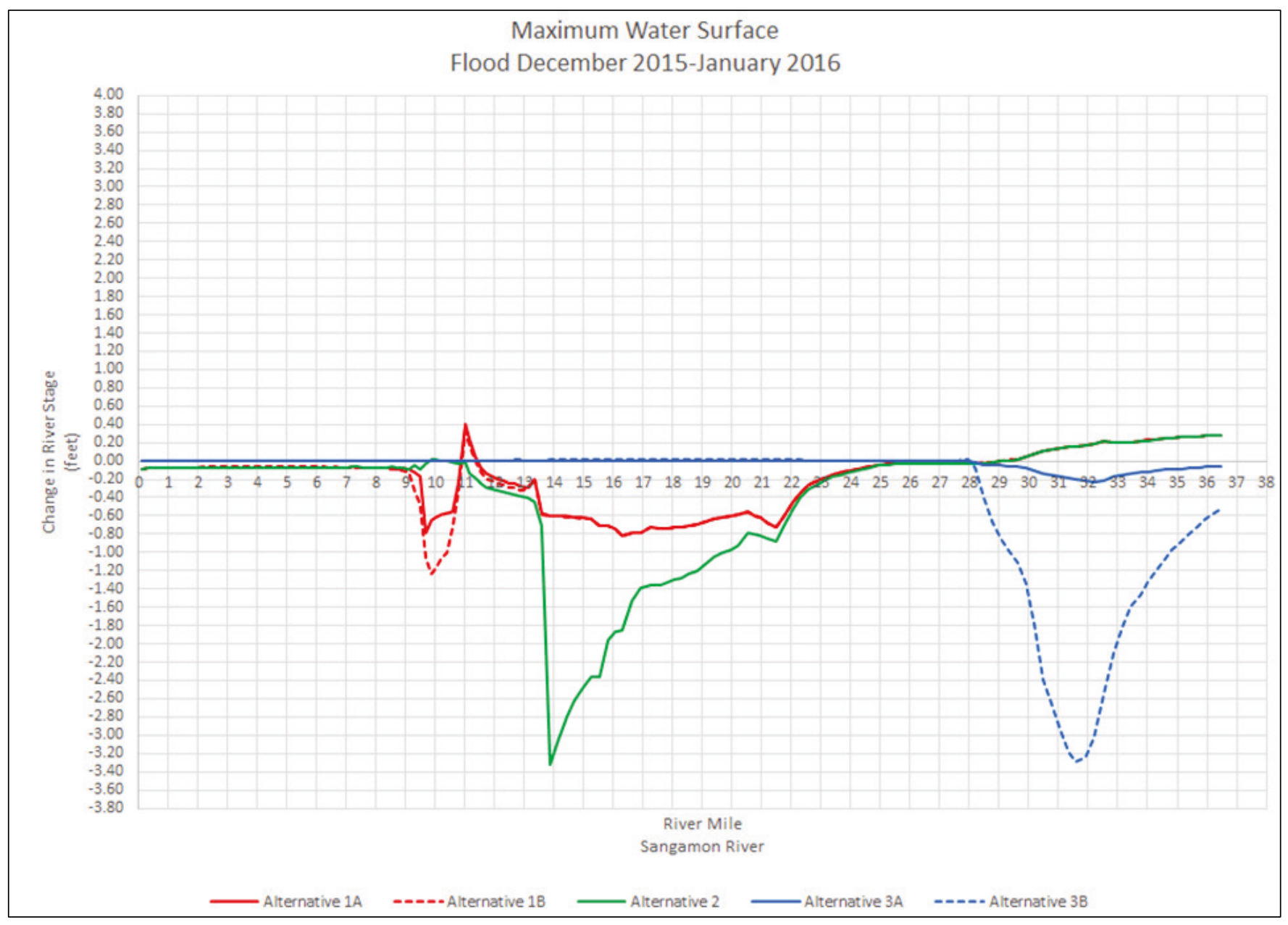


Figure 19. Modeled Lower Sangamon River bed elevation response to flooding under the base condition.

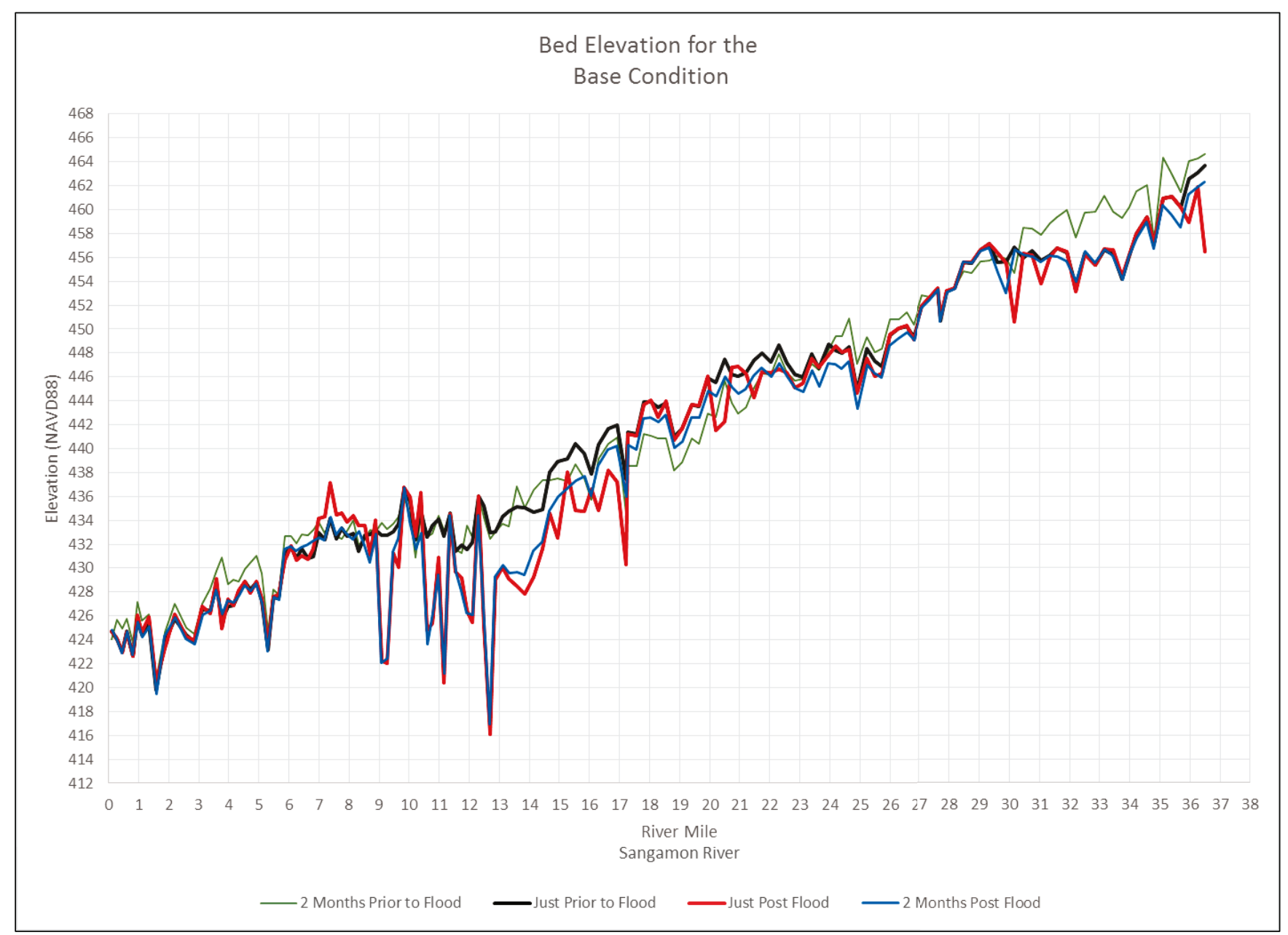


Figure 20. Lower Sangamon River bed elevation response to five levee setback alternatives, prior to flooding.

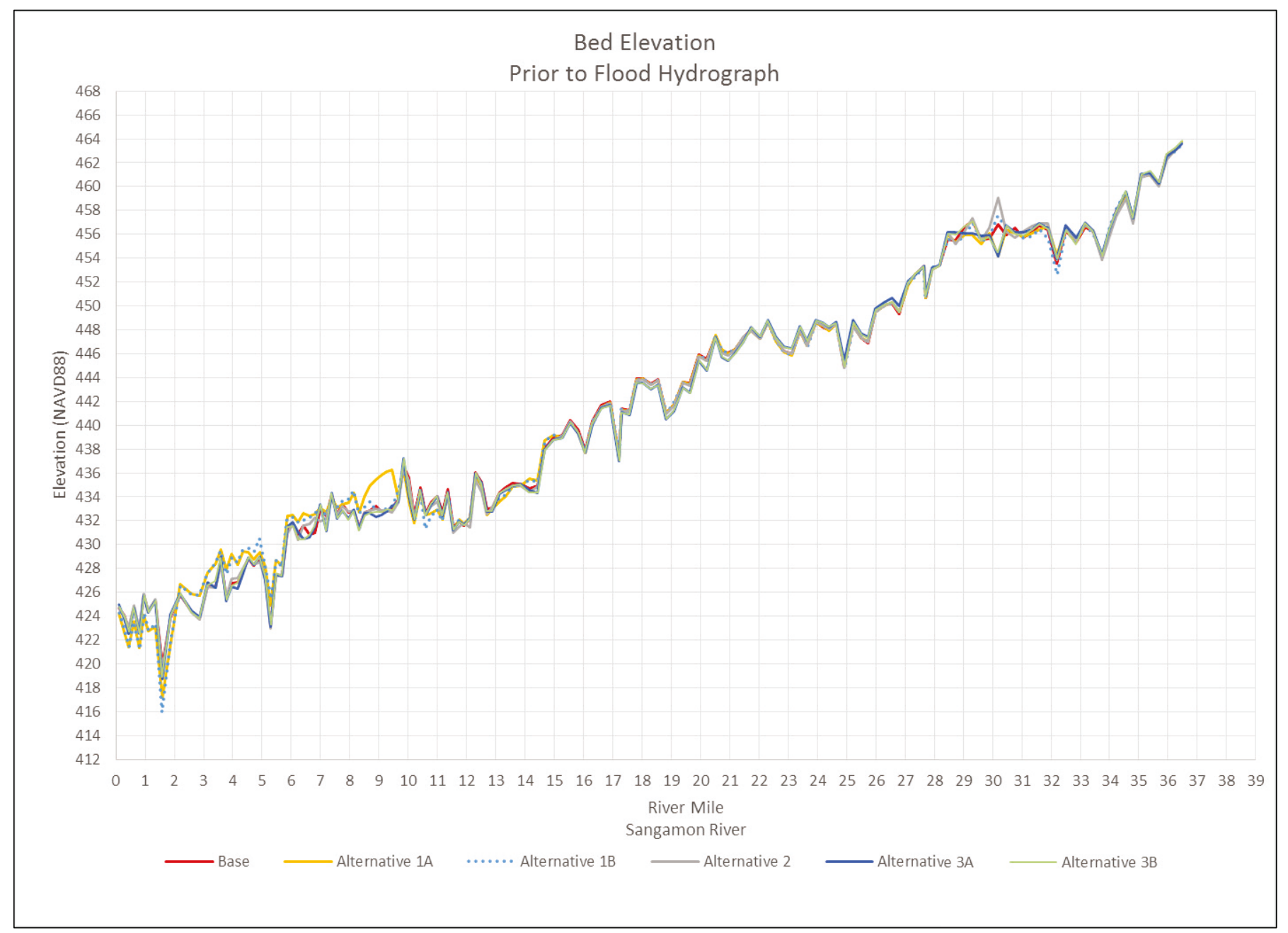


Figure 21. Lower Sangamon River bed elevation response to five levee setback alternatives immediately after flooding.

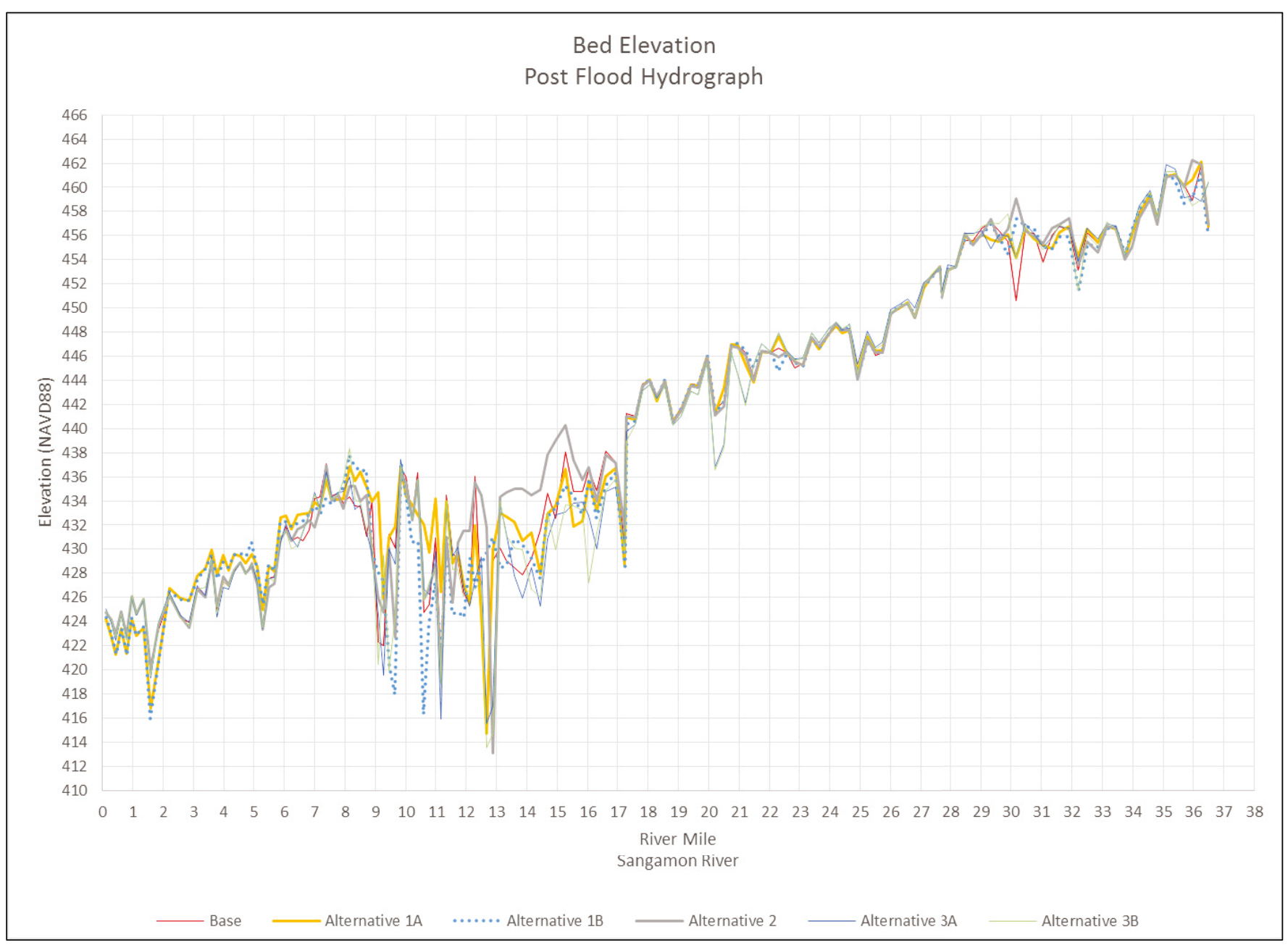




\section{Figure 22. Lower Sangamon River bed elevation response to five levee setback alternatives, 2 months after flooding.}

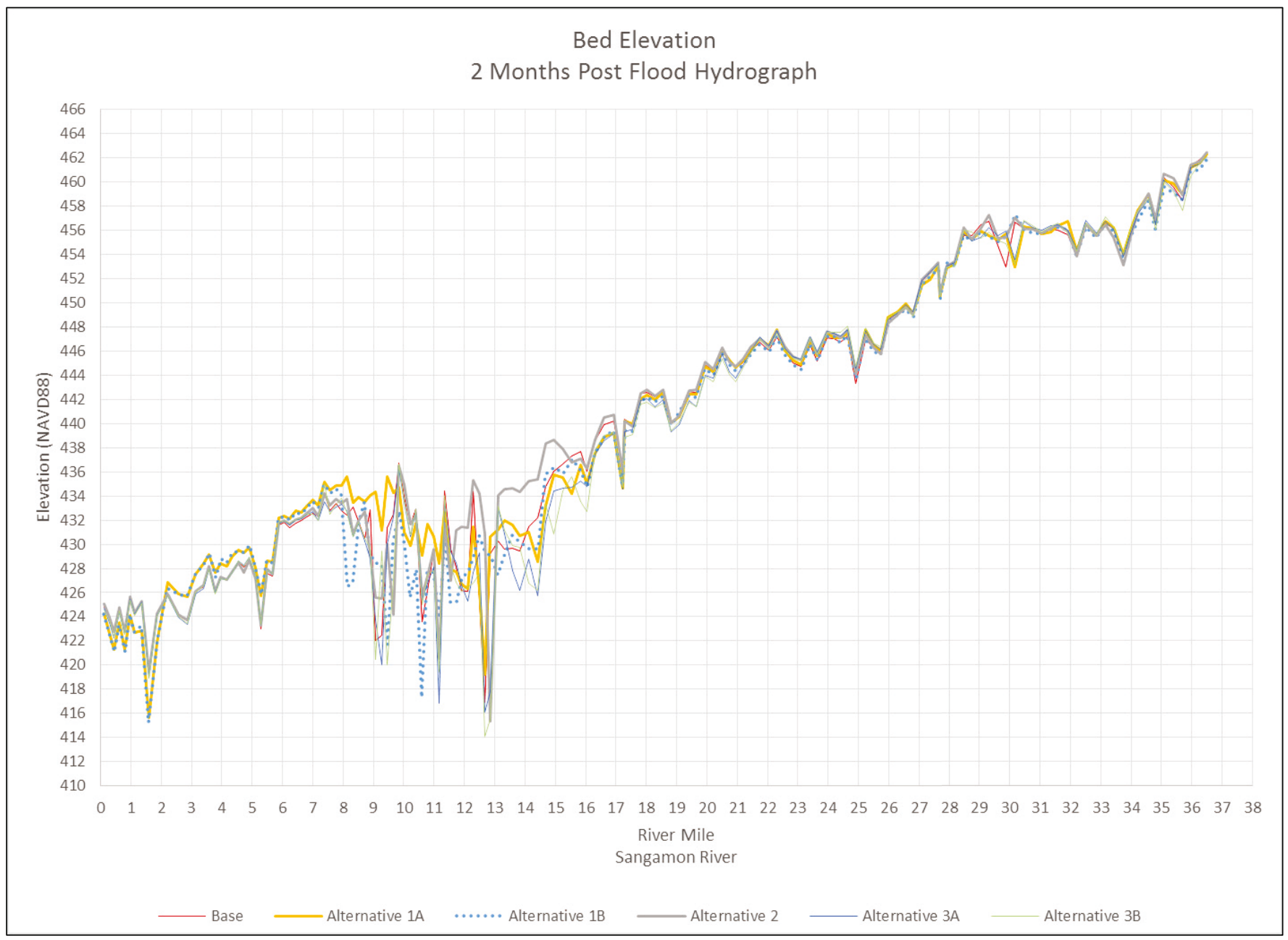


The overbank deposition results demonstrate the effects of the sediment transport properties that have filled the conservation area over the last 70 years.

Alternatives $1 \mathrm{~A}, 1 \mathrm{~B}$, and $3 \mathrm{~A}$ transport sediment similarly in model simulations. All three transport more sediment through RM 20 to 12, relative to the base condition. Sediment transport decreases dramatically below RM 12, again demonstrating the influence of the conservation area on sediment transport. Alternative $1 \mathrm{~B}$ is unique in that it retains all sediment in the tributary floodplain and transports none to the main stem.

Alternative 2 transports sediment in a similar manner to the base condition. The two scenarios diverge at RM 15 where Alternative 2 retains approximately 500,000 $\mathrm{yd}^{3}$ more sediment than the base condition.

Alternative $3 \mathrm{~B}$ was conceived to retain sediment, and it performs better at retaining sediment on the floodplain than the other alternatives. The levee removal retains 2.5 million $\mathrm{yd}^{3}$ of sediment between $\mathrm{RM} 30$ and the right bank natural levee at RM 17. The sediment load does not increase, thus protecting the Sanganois Conservation Area. Alternative $3 \mathrm{~B}$ performs similarly to other alternatives in the lower reaches of the river as sediment moves through the Sanganois Conservation Area. 
Figure 23. Total sediment delivered through the lower Sangamon River (left axis, Base) and the difference attributable to five levee setback alternatives (right axis).

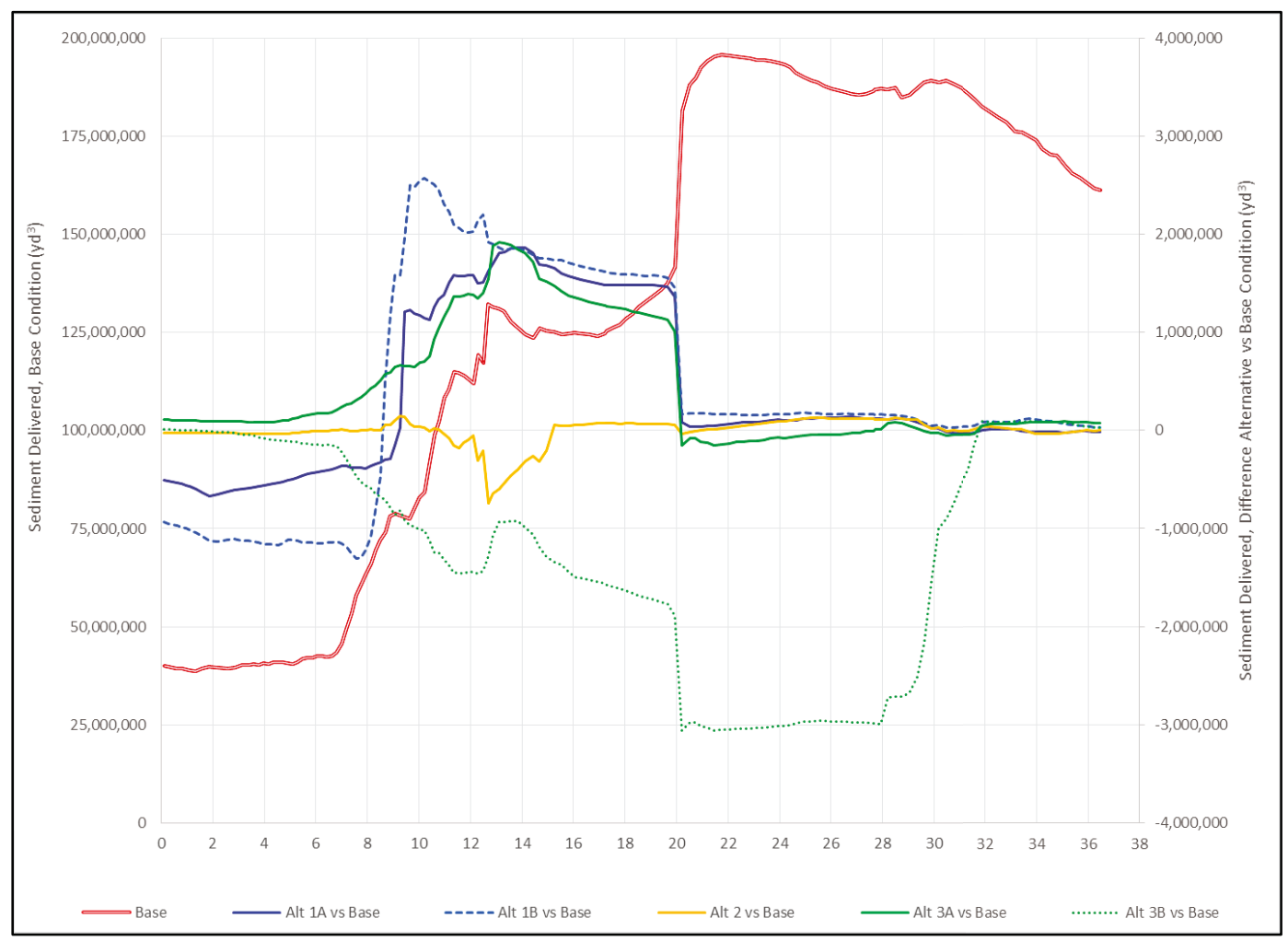

\subsection{Land cover and connectivity}

Land cover change is a potential outcome of management actions to reduce flood risk by increasing floodplain connectivity. Change potential depends largely on the mode and frequency of increased connectivity. Controlled overflows or gates support farming in most years until flooding triggers emergency response and cropland is flooded. Conversely, levee removal precludes farming because large areas would be flooded during most years. Potential land cover change was largest with levee removal Alternatives $1 \mathrm{~B}$ and $3 \mathrm{~B}$, where 8,500 and 3,150 acres, respectively, of cropland would be converted to connected floodplain (Figure 24; Table 2). That implies a commensurate increase in conservation objectives and restoration of diverse native plant and wildlife communities suited to site conditions and management.

Alternative 2, which connects private hunting/conservation areas and cropland, has the highest environmental benefits because of the existing habitats in that location. There are 110 acres of wetland and 1,733 acres of forest managed for waterfowl using existing aquatic areas as independent management units. Levee removal inundates the area more often and 
would introduce sediment that would impact landowners and their existing land uses. Alternative 2 would also require substantial coordination with the Sanganois Conservation Area and multiple private and public landowners there. Restoring historic river meanders could increase connectivity through the entire tributary delta, but that comes with associated challenges for sediment management.

Figure 24. Potential land cover connected by five levee setback alternatives for the lower Sangamon River floodplain. Alternatives $1 \mathrm{~A}$ and $3 \mathrm{~A}$ use gates to support existing conditions during typical floods.

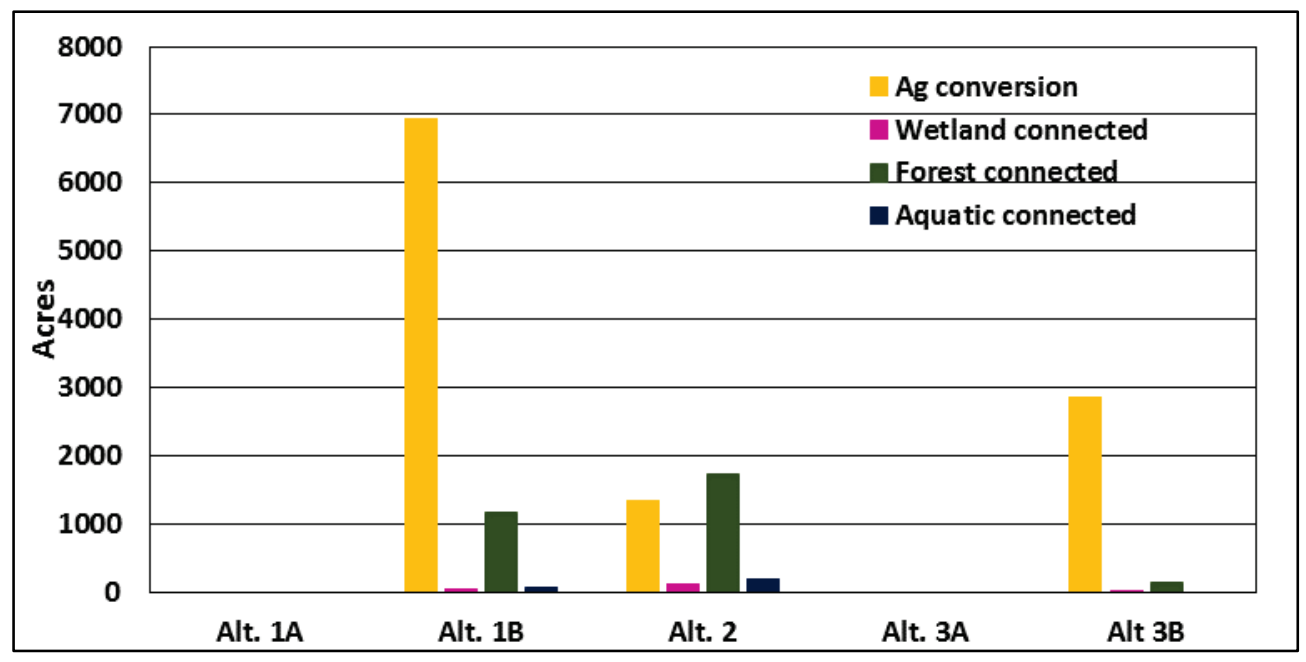

\subsection{Benefit matrix}

In an effort to further emulate a SMART planning (USACE 2012) approach, selected resources (i.e., agriculture, habitat, and ecosystem services) were ranked to facilitate rapid evaluation and display effects of alternative plans (USACE 2000). This is a subjective assignment by subject matter experts in this case, but it is an example of the level of detail that can be achieved in rapid prototype planning with stakeholder groups. A summary table (Table 2) coupled with simple graphics (Figure 25) can rapidly convey complex engineering, ecological, and planning information for broad-based audiences. A more complex evaluation might combine benefits into a single index unit related to the number of acres affected.

Physical response results, stage reduction, bedload retention, and overbank retention, were simplified as single units to facilitate their display (Figure 25, Panel A). Maximum stage reduction (feet) is a simple unit to understand, but its scale must be explained in terms of the frequency that damaging floods would be reduced and area impacted by a particular project. Alternatives 2 and $3 \mathrm{~B}$ have the greatest stage reduction 
benefit, but the spatial distribution of benefits differs among them all. Alternative 3B could protect levees upstream of RM 20, and Alternative 2 could protect levees for RM 10-20. There would be potential to coordinate multiple levee setbacks along river reaches to tailor FRM to any floodplain setting. Levee setbacks above municipalities or floodways around them may be viable alternatives compared to building urban levees higher. Other mission area benefits could also be incorporated into plan formulation (Table 2 and Figure 25) using structured decision-making tools to compare features and alternatives.

Land cover response is frequently summarized in acres to compare ecosystem restoration habitat outcomes. The use of acres and general habitat classes (Figure 25, panel B) is a very simple and familiar representation of habitat benefits with total area setback included for reference in Table 2. Alternative 2 illustrates existing habitat diversity while the substantial land conversion potential of Alternatives $1 \mathrm{~B}$ and $3 \mathrm{~B}$ represents a significant gain in potential habitat diversity. That gain in diversity, however, would come as a significant impact on existing land uses and private land ownership. The intermediate alternative using agricultural areas as emergency flowage easements to reduce flood risk and protect levees from catastrophic failure does not show substantial stage reduction benefits and sediment transport in the lower reaches is increased. The minimal stage response might be worthy of further investigation, however, because of the location adjacent to Beardstown. Even small stage reductions can provide substantial social and economic benefits during floods with relatively minimal impacts on cropland when structures are removed.

The summary of selected resources (i.e., agriculture, habitat, and cosystem services) is undeveloped and insufficient for project planning in its present form, but it is presented to demonstrate how complex planning concepts could be simplified for integrated planning settings. This rapid prototype modeling approach that incorporates detailed technical information into simple values can be a helpful plan formulation tool. Interdisciplinary stakeholder groups can use the approach to visualize the impacts of environmental, economic, and social factors and respond to them together as a group that can explain their modeling/planning objectives and assumptions. Achieving clear stakeholder consensus can lead to broadbased solutions and rapid project approval. 
In this case economic benefits were oversimplified as agricultural losses. In reality there are potential trade-offs with reduced navigation dredging, FRM, and environmental management costs with increases in recreational spending and alternative crops. Substantial planning would be required to implement any floodplain management alternative. The greatest agricultural impacts are associated with levee removal, followed by flood easements, and the least impacts are associated with Alternative 2. Habitat benefits are high with levee removal. The incremental benefit of improving and connecting existing habitat in Alternative 2 is not comparable to the large benefit from cropland conversion. Ecosystem service benefits are complex in this area because of the location of the town at the exact confluence of the Sangamon and Illinois Rivers. The levee-protected city is subject to the combined impacts of flooding, channelization, sedimentation, climate change, watershed channelization, levee degradation, and other factors on the physical infrastructure and safety of the town. The economic vitality of the region, however, is intimately linked to and supported by the agriculture industry surrounding it. Ecosystem services in this case were simplified in the example to include benefits of reduced flood risk, increased habitat potential, and potential sediment and nutrient reduction in overbank areas subject to flooding. 
Figure 25. Levee setback benefit/harm plot of physical (stage, sediment retention), ecological (land cover), and planning considerations.

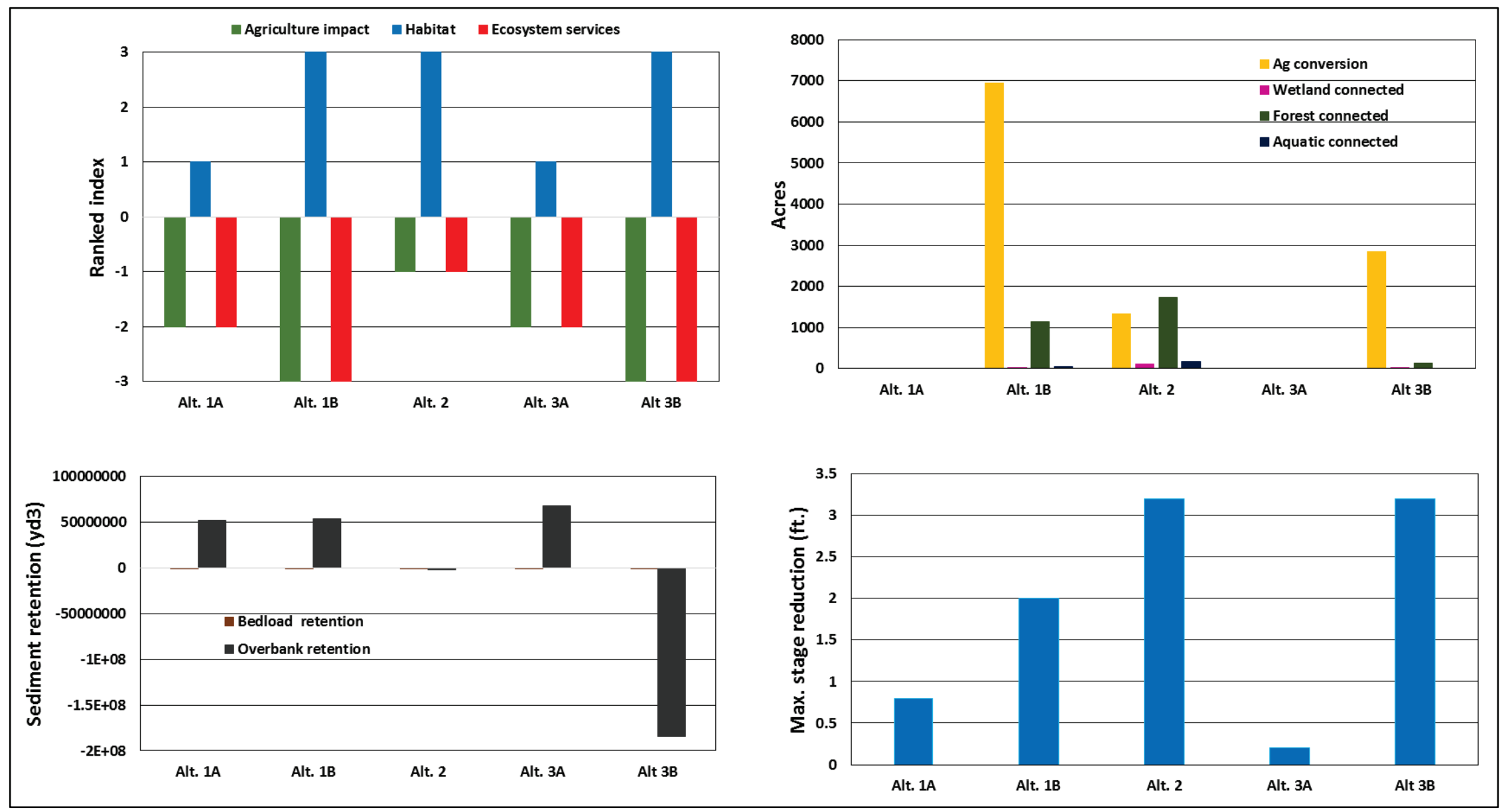




\section{Discussion}

Levee setback alternative analysis demonstrated potential for alternatives to reduce river stages, though benefits differed and their performance on other USACE missions varied. Implications of each alternative will be discussed briefly, but it is important to acknowledge the difficulty of managing multiple, interconnected interests in this region. Bountiful river resources and human exploitation of them built the regional infrastructure, which is becoming overwhelmed by age and overcapacity. Several record and nearrecord floods have stressed old levees where landowners were already trying to make critical repairs. While flood protection may be the primary consideration in this agricultural region, navigation is another important economic and cultural factor. Dredging at the mouth of the Sangamon River produces large quantities of sand that are currently stockpiled on prime farmland, with no good alternative. Retaining sand in the floodplain would be a cost savings up to $\$ 1$ million annually to navigation operations. Ecosystem restoration is the third area that USACE actions substantially influence this reach. Channelizing the Sangamon River changed sediment transport dynamics in 1949, and the impacts were still evident in this sediment transport model. The massive drop in sediment loads between RM 12 to 7 across all scenarios (Figure 23) is attributed to its transport into the Sanganois Conservation Area, but the 1D model does not specifically simulate that process. Retaining sediment before it gets to the Conservation Area would be a substantial ecosystem restoration benefit. Trade-off analysis is an important element of USACE planning process.

Alternatives $1 \mathrm{~A}$ and $1 \mathrm{~B}$ altered levees in agricultural land near the river mouth. While conceived for high flood reduction benefits, these alternatives had the least stage reduction benefit. Interestingly, both the gated and levee removal alternatives showed similar physical performance. Overbank sediment transport benefits were reduced upstream of the setbacks (Figure 23), but the entire load was transported to the Sanganois overbank area downstream for little change at the mouth. There are some interior wetlands in this setback area, but most of the environmental benefit comes from cropland conversion in Alternatives $1 \mathrm{~B}$ and $3 \mathrm{~B}$.

Alternative 2 was conceived as a conservation alternative that would have minimal impact on agriculture. The stage reduction benefits exceeded $3 \mathrm{ft}$ 
maximum and $>1 \mathrm{ft}$ reduction extended over 6 miles along the Old River and Hager Slough Levee and Drainage Districts, which would have less flood exposure. Sediment retention benefits of Alternative 2 do not exceed the baseline considerably, but habitat connectivity benefits are highest. Connecting existing habitat is beneficial for river processes, and there is substantial opportunity if integrated with Sanganois Conservation Area restoration. Sediment transport into the setback area and the Conservation Area would raise significant management and cultural considerations to overcome. From a management perspective, sediment is overwhelming aquatic habitats, which have lost $10 \mathrm{ft}$ of depth in addition to the landform change (Figure 3). Culturally, the loss of traditional hunting/recreation areas is important to Illinois River communities. Conceptual modeling undertaken in 2015 identified sedimentation and its multiple sources and sinks among the primary inter-related problems in the region.

Alternatives $3 \mathrm{~A}$ and $3 \mathrm{~B}$ were conceived as sediment traps to capture Sangamon River main stem and Crane Creek sediment in separate management units upstream from a highway berm crossing the floodplain and constraining river flow between bridge priers (Figure 10). The levee removal alternative had a large $3 \mathrm{ft}$ stage reduction effect that would extend 6 miles along the lower end of the Mason \& Menard Levee and Drainage District. Sediment retention benefits were best for Alternative $3 \mathrm{~B}$, which outperformed all other alternatives (Figure 24). Overbank sediment was retained in the levee removal area for 5 miles above the highway and in connected floodplains for 5 miles below the bridge.

This modeling study demonstrates the potential to use existing hydrologic models for rapid planning exercises. There is regional skepticism and inexperience with environmental modeling but also an openness to learning. Several research and development initiatives have been focused on this site specifically because of its contentious history and high political profile. Sediment management drives most USACE spending in the region, so Regional Sediment Management (RSM)-funded studies built and calibrated a sediment transport model. This study built on that RSM model to support levee setback research. It did not enlist planning rigor nor broad participation from others, but it does demonstrate how modeling tools could be used for that purpose. It also benefited FRM investigations using the record 2015-2016 flood as a calibration event. There were limitations on interpretation of overbank sediment retention results because of model uncertainty. Floodplain sedimentation studies 
are being implemented to strengthen those estimates through better calibration. Questions regarding the fate of nutrients will be investigated using a simple spreadsheet modeling approach in a follow-on study. ${ }^{1}$

1 Bartell, S. M., C. T. Woodard, C. H. Theiling, and T. A. Dahl. In preparation. Development and Application of the CASM-SL to Support Nutrient Management in Potential Sangamon River Levee Setbacks. ERDC Technical Report. Vicksburg, MS: U.S. Army Engineer Research and Development Center. 


\section{Summary}

This rapid planning exercise demonstrating levee setback benefits supports U.S. Army Corps of Engineers (USACE) SMART planning (USACE 2012) which strives for efficiency and completeness in alternative analysis and evaluation. It used existing information and models to consider alternative floodplain management scenarios. Modeling scenarios integrated USACE missions and used extreme examples to illustrate the potential magnitude of environmental response. Three environmental management scenarios emphasizing flood, conservation, and sediment reduction benefits were compared in simple index units and summary graphs suitable for executive summary.

Results from simple, rapid prototype modeling could help prioritize measures and plan formulation alternatives. Future improvements to the model could quantify the economic impacts to agriculture using crop values and better inundation mapping tools. Habitat benefit estimates could be improved by estimating land cover potential in the project areas over 50 years. Ecosystem service benefit estimates would be greatly improved by adding nutrient processing in inundated areas and by quantifying the flood reduction benefits to Beardstown, IL. 


\section{References}

American Society of Civil Engineers (ASCE). 2013. 2013 Report Card for America's Infrastructure. American Society of Civil Engineers. http://www.infrastructurereportcard.org/wp+content/uploads/2013ReportCardforAmericasInfrastructure.pdf.

Bogue, M. B. 1951. "The Swamp Land Act and Wet Land Utilization in Illinois.” Agricultural History 25: 169-180.

Cargill, Inc. 2014. "Cargill Illinois Pork Plant Reaches 6 Million Work Hours with No Lost Time to Injuries.” http://www.cargill.com/news/releases/2014/NA31701457.jsp.

Dahl, T. A., C. H. Theiling, and W. Echevarria. 2017. Overview of Levee Setback Projects and Benefits. ERDC/CHL CHETN-VII-17. Vicksburg, MS: U.S. Army Engineer Research and Development Center. http://dx.doi.org/10.21079/11681/22767.

Echevarria-Doyle, W., and T. A. Dahl. 2018. Numerical Hydrodynamic Study of Hypothetical Levee Setback Scenarios. ERDC/CHL TR-18-1. Vicksburg, MS: U.S. Army Engineer Research and Development Center. http://dx.doi.org/10.21079/11681/26361.

Illinois Geospatial Data Clearinghouse. 2016. Illinois Height Modernization (ILHMP): LiDAR Data. http://clearinghouse.isgs.illinois.edu/data/elevation/illinois-heightmodernization-ilhmp-lidar-data.

Illinois State Museum. 2016. Harvesting the River. http://www.museum.state.il.us/RiverWeb/harvesting/.

Jones, K. E., T. A. Dahl, and Z. P. Corum. 2018. Modeled Sedimentation in the Lower White River Countyline Levee Setback, Washington State: Comparison of $1 D$ (HEC-RAS) and 2D (AdH) Results. ERDC/CHL TR-18-9. Vicksburg, MS: U.S. Army Engineer Research and Development Center.

Mississippi River Commission. 2007. The Mississippi River and Tributaries Project: Floodways. Mississippi River Commission, Vicksburg, MS.

Pavlowski, R. T., M. C. Pierson, M. R. Owens, J. C. Voss, and N. R. Weedman. 2016. Big River Lead Remediation Structure (BRLRS) Monitoring Project. Springfield, MO: Ozarks Environmental and Water Resources Institute (OEWRI), Missouri State University (MSU).

Rhodes, B. L., Q. W. Lewis, and W. Andresen. 2016. "Historical Changes in Channel Network Extent and Channel Planform in an Intensively Managed Landscape: Natural Versus Human-Induced Effects." Geomorphology 252: 17-31.

Smith, D. L., S. P. Miner, C. H. Theiling, R. Behm, and J. M. Nestler. 2017. Setback Levees: An Innovative, Cost-Effective, and Sustainable Solution for Improved Flood Risk Management. ERDC/EL SR-17-3. Vicksburg, MS: U.S. Army Engineer Research and Development Center. 
Sommer, T. R., W. C. Harrell, M. Nobriga, R. Brown, P. B. Moyle, W. J. Kimmerer, and L. Schemel. 2001. "California's Yolo Bypass: Evidence That Flood Control Can Be Compatible with Fish, Wetlands, Wildlife and Agriculture.” Fisheries 26(8): 6-16.

Stanford University National Performance of Dams Program. 2016. Largest U.S. Reservoirs. https://npdp.stanford.edu/node/63.

Thompson, B., R. Behm, and D. Crane. 2013. "Envisioning a New River Future with Greater Societal and Wildlife Benefits: Large-scale Levee Setbacks along the Missouri River." National Conference on Ecosystem Restoration, July 29-August 2, 2013, Chicago, IL. http://www.conference.ifas.ufl.edu/ncer2013/Presentations/4Innovation/2-Wednesday/27-Session/YES/0440\%20Thompson.pdf.

Thorp, J. H., M. C. Thoms, and M. D. Delong. 2006. "Riverine Ecosystem Synthesis: Biocomplexity in River Networks across Space and Time." River Research and Applications 22: 123-147.

U.S. Army Corps of Engineers (USACE). 2000. Planning Guidance Notebook. ER 1105-2100. U.S. Army Corps of Engineers, Washington, DC.

2004. General Investigation Reconnaissance Survey: Beardstown, Illinois. Rock Island, IL. U.S. Army Corps of Engineers, Rock Island District.

2011. Final Feasibility Report and Environmental Impact Statement: FargoMoorhead Metropolitan Area Flood Risk Management. St. Paul, MN: U.S. Army Corps of Engineers, St. Paul District.

2012. Planning SMART Guide. U.S. Army Corps of Engineers Planning Bulletin, CECE-P, No. PB 2012-02, Reissue \# 2.

. 2016a. HEC-RAS River Analysis System, User's Manual, Version 5.o. Davis, CA: U.S. Army Corps of Engineers, Hydrologic Engineering Center.

2016b. Partners in Shared Responsibility. http://www.iwr.usace.army.mil/Missions/Flood-Risk-Management/Flood-Risk-ManagementProgram/Partners-in-Shared-Responsibility/.

2016c. Historical Vignette: The Pick-Sloan Plan. http://www.nwo.usace.army.mil/Media/Fact-Sheets/Fact-Sheet-ArticleView/Article/610414/historical-vignette-the-pick-sloan-plan/.

2016d. Nonstructural Flood Risk Management Measures. http://www.nwdmr.usace.army.mil/rcc/MRFT/docs/USACENFPC\%20Nonstructural\%20Measures\%20Definitions.pdf.

Wikipedia. 2016. List of Largest Lakes of the United States by Area. https://en.wikipedia.org/wiki/List_of_largest_lakes_of_the_United_States_by_area. 


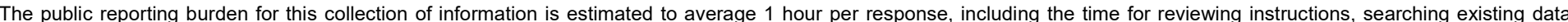

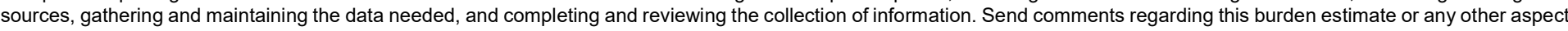

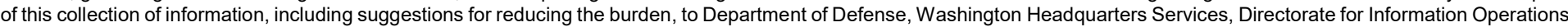

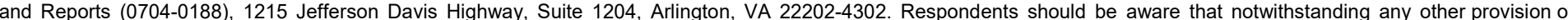
law, no person shall be subject to any penalty for failing to comply with a collection of information if it does not display a currently valid OMB control number.

PLEASE DO NOT RETURN YOUR FORM TO THE ABOVE ADDRESS.

\begin{tabular}{|l|l|l|}
\hline 1. REPORT DATE & 2. REPORT TYPE & 3. DATES COVERED (FrOm - TO)
\end{tabular}

August 2018

4. TITLE AND SUBTITLE

Final Report

Levee Setback Utility for Mission Integration in the Sangamon River Floodplain:

Illinois Waterway

5a. CONTRACT NUMBER

5b. GRANT NUMBER

5c. PROGRAM ELEMENT NUMBER

6. AUTHOR(S)

Charles H. Theiling, Thomas A. Kirkeeng, Christopher P. Haring,

and Travis A. Dahl

5d. PROJECT NUMBER

454633

5e. TASK NUMBER

5f. WORK UNIT NUMBER

7. PERFORMING ORGANIZATION NAME(S) AND ADDRESS(ES) (see reverse)

8. PERFORMING ORGANIZATION REPORT NUMBER

ERDC TR-18-12

9. SPONSORING/MONITORING AGENCY NAME(S) AND ADDRESS(ES)

U.S. Army Corps of Engineers

10. SPONSOR/MONITOR'S ACRONYM(S)

USACE

Washington, DC 20314-1000

\section{SPONSOR/MONITOR'S REPORT} NUMBER(S)

12. DISTRIBUTION/AVAILABILITY STATEMENT

Approved for public release; distribution is unlimited.

\section{SUPPLEMENTARY NOTES}

\section{ABSTRACT}

This document presents a levee setback case study on the Sangamon River near Beardstown, IL. Five potential setback scenarios were tested using a Hydrologic Engineering Center-River Analysis System (HEC-RAS) hydraulic and sediment model. HEC-RAS results demonstrated differences in flood reduction and sediment trapping opportunities among gate opening and levee-removal scenarios. Levee removal upstream of a bridge and causeway provided the greatest sediment reduction potential. Increasing flow into connected floodplain areas offered intermediate flood and sediment reduction benefits but did not improve natural resource benefits. Levee removal and land conversion provided the greatest natural resources benefit, but substantial economic loss. This study demonstrates the potential benefits of levee setbacks across the U.S. Army Corps of Engineers navigation, ecosystem restoration, and flood management mission areas.

\section{SUBJECT TERMS}

Environmental management, Flood control, Floodplain management, Sangamon River (Ill.)_-Levees, Sangamon river (Ill.)_-Sediment transport, Stream restoration

\section{SECURITY CLASSIFICATION OF:}

\begin{tabular}{|l|l|l|}
\hline a. REPORT & b. ABSTRACT & c. THIS PAGE \\
Unclassified & Unclassified & Unclassified \\
\hline
\end{tabular}

17. LIMITATION OF
ABSTRACT
SAR

\section{NUMBER OF PAGES}

50 19a. NAME OF RESPONSIBLE PERSON Travis A Dahl

19b. TELEPHONE NUMBER (Include area code) 601-634-2371 
7. PERFORMING ORGANIZATION NAME(S) AND ADDRESS(ES) (continued)

Environmental Laboratory

U.S. Army Engineer Research and Development Center 3909 Halls Ferry Rd

Vicksburg, MS 39180-6199

U.S. Army Corps of Engineers, Rock Island District

P.O. Box 2004, Clock Tower Bldg

Rock Island, IL 61204-2004

Coastal and Hydraulics Laboratory

U.S. Army Engineer Research and Development Center 3909 Halls Ferry Rd

Vicksburg, MS 39180-6199 